\title{
Organic Corrosion Inhibitors
}

\author{
Bogumił Eugeniusz Brycki, Iwona H. Kowalczyk, \\ Adrianna Szulc, Olga Kaczerewska and Marta Pakiet
}

Additional information is available at the end of the chapter

http://dx.doi.org/10.5772/intechopen.72943

\begin{abstract}
Organic corrosion inhibitors are one of the five ways, besides material selection, design, cathodic protection and coatings, to protect materials against corrosion. Corrosion is an ubiquitous phenomena that deteriorates all materials, metals, plastics, glass and concrete. The costs of corrosion are tremendous and amounts to $4.0 \%$ of gross domestic product (GDP) in USA. The similar losses of GDP are noted in all countries around the world. At this point of time, there is no way to completely stop the corrosion processes. Some new solutions can only slow this process. Organic corrosion inhibitors are widely used in industry because of their effectiveness at wide range of temperatures, compatibility with protected materials, good solubility in water, low costs and relatively low toxicity. Organic corrosion inhibitors adsorb on the surface to form protective film which displace water and protect it against deteriorating. Effective organic corrosion inhibitors contain nitrogen, oxygen, sulfur and phosphorus with lone electron pairs as well can contain structural moieties with $\pi$-electrons that interact with metal favoring the adsorption process. This review presents mechanisms and monitoring of corrosion, laboratory methods for corrosion study, relationship between structure and efficacy of corrosion inhibitions, theoretical approach to design new inhibitors and some aspects of biocorrosion.
\end{abstract}

Keywords: organic corrosion inhibitors, biocorrosion, sulfate-reducing bacteria gemini surfactants, corrosion tests

\section{Introduction}

The world we live in is chemical. Everything what surrounds us is composed of natural or synthetic chemical compounds. Some of them are very durable, some of them are less stable. But all of them are subjected to interactions with the environment what adversely affects the 
structural performance, including reliability over time. The deterioration process concerns all materials, not only metals but also plastics, glass, concrete, wood, leather and paper. The cracking, swelling, crazing, discoloration, phase separation or delimitation of plastics is caused by UV-light, heat, moisture or biological activity, that is, by physical, chemical or biological reactions [1, 2]. Corrosion of glass is due to reactions with atmospheric pollutants such as $\mathrm{SO}_{2}$ or $\mathrm{CO}_{2}$ as well as hydroxyl ions attack on siloxane bonds what leads to extraction of silica $[3,4]$. Corrosion of concrete materials is also a very important economic problem. The maintenance costs of concrete microbial corrosion (CMC) of sewer pipelines in Hamburg (Germany) in 1970s reached up to $€ 25$ million whereas in Los Angeles (USA), the sewer pipe of $208 \mathrm{~km}$ in a total length of $1900 \mathrm{~km}$ had been damaged by CMC, and the rehabilitation costs were as high as \$400 million [5]. Wood may also cleave or decompose what is related to its chemical structure based on cellulose, lignin and hemicelluloses. In natural environment, wood is rapidly colonized by microorganism and insects and the process of decomposition begins [68]. Deterioration of wood materials is a serious problem especially for historic wood pieces and monuments [9-11].

The deterioration of different kind of materials is defined as corrosion by American Society for Testing and Materials (ASTM International), that is, "the chemical or electrochemical reaction between a material, usually a metal, and its environment that produces a deterioration of the material and its properties" [12]. However, the most undesirable and noticeable is corrosion of metals which is defined by ISO (International Organization for Standardization) as "physicochemical interaction between a metal and its environment that results in changes in the properties of the metal, and which may lead to significant impairment of the function of the metal, the environment, or the technical system, of which these form a part" [13]. Total costs of corrosion include "the design and construction or manufacturing, the cost of corrosion-related maintenance, repair and rehabilitation, and the cost of depreciation or replacement of structures that have become unusable as a result of corrosion" [14] and is estimated to be US\$2.5 trillion what corresponds to $3.4 \%$ of the global GDP (2013). The use of current corrosion control practice and procedures, including organic corrosion inhibitors, would allow to save $15-35 \%$ costs of corrosion [14]. The cost of corrosion varies depending on branch of industry and usually it is the highest in transportation and chemical industry. In China in 2014, direct corrosion cost in transportation was 268.72 billion RMB that constitutes $23.97 \%$ of total corrosion costs [15].

Corrosion is an ubiquitous phenomena and there is no way to completely stop it. Some new solutions can only slow this process. However, the environmental pollution, global warming and climate change are the direct cause for increasing corrosion costs. Only the increase of global temperature by $2^{\circ} \mathrm{C}$ causes an increase of corrosion rates by up to $15 \%$ [16].

\section{Mechanism of corrosion}

Corrosion is mainly induced by chemical and electrochemical processes. Chemical corrosion takes place in dry gases and nonconductive liquids where there is no current/electron flow. The 
main effect of chemical corrosion is an oxide layer as a result of oxidation in the air [17]. Electrochemical corrosion takes place in solution, between metallic materials and electrolytes due to different potentials on the surface of the corroded metal and due to redox reactions. One part of the metal is anode where metal oxidizes and becomes ion.

$$
\mathrm{M} \rightarrow \mathrm{M}^{\mathrm{n}+}+\mathrm{n} e
$$

The another part is cathode, where depolarization takes place, mainly reduction of oxygen and hydrogen cation $[15,16]$.

$$
\begin{gathered}
\mathrm{O}_{2}+4 \mathrm{H}^{+}+4 e \rightarrow 2 \mathrm{H}_{2} \mathrm{O} \\
2 \mathrm{H}^{+}+2 e \rightarrow \mathrm{H}_{2} \uparrow
\end{gathered}
$$

A scheme of electrochemical corrosion is shown in Figure 1.

Another type of corrosion is biocorrosion, commonly called microbial-induced corrosion (MIC) and is defined as deterioration of metallic material caused by consortia of microorganisms [20]. Microbes form a biofilm on the metal surface which is very good environment for their growth [21]. Biofilms are multicellular communities of bacteria encased in an extracellular matrix of exopolysaccharide, protein and sometime extracellular nucleic acids [22]. Biofilms are very hard to eradicated from any environment. They are resistant to most antimicrobial agents [23]. Sulfate-reducing bacteria (SRB) and sulfur-oxidizing bacteria which form biofilm to large extend are the main reason of the biocorrosion [21].

Another term associated with material's degradation is erosion which means "a progressive loss of original material from a solid surface due to mechanical interaction between the surface and a fluid, a multicomponent fluid or impinging liquid or solid particles" [24]. A process involving conjoint corrosion and erosion is named corrosion-erosion [24].

\section{Electrolyte}

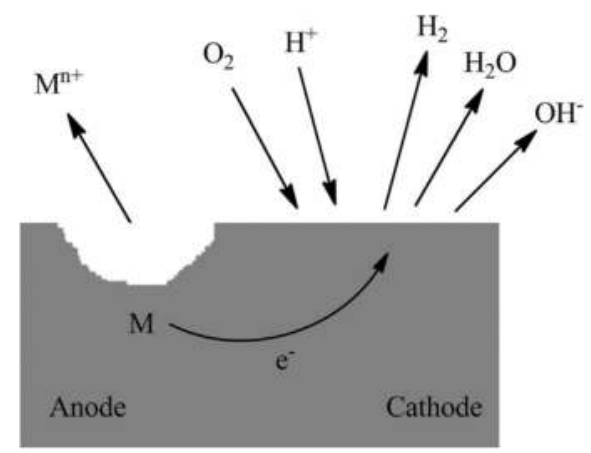

Figure 1. Scheme of electrochemical corrosion. 


\section{Monitoring of corrosion}

To estimate real corrosion damage, many direct and indirect physicochemical analytical methods are used [25]. The most basic method is visual inspection [15, 23]. However, many non-intrusive methods are commonly applied, like ultrasonic [27], potential measurements, radiography, eddy current, magnetic particle inspection [28] and acoustic emission [29]. Ultrasonic allows to control thickness by using sonic waves with high frequency $(1-6 \mathrm{MHz})$. The method can be used for liquids and solids but not for gases [28]. The equipment is calibrated on two thicknesses and by collecting data of material sound velocity, the thickness is calculated. The method can be used inservice and also allows to measure pipe with high temperature and over coatings [27]. The advantage of this method is a possibility to access the material only from one side. The surface of material has to be prepared carefully to have a good contact with the equipment $[18,19]$. Acoustic emission measures acoustic sound waves which are emitted due to deformation in the monitored material. The sensors are very sensitive microphones. The sound waves are produced from mechanical stress (pressure or temperature changes) so the technique does not need excitation or human intervention [30]. This technique is a source of large amount of data which requires elaborate filtering and analysis [29]. Potential measurements to control corrosion can be done with a voltmeter with high internal resistance. To get results, the equipment has to be connected to a reference electrode (usually $\mathrm{Ag} / \mathrm{AgCl}$ electrode). Another method, radiography, uses ability of gamma radiation to penetrate the investigated material. When the beam passes through the material, some energy is absorbed in the material. The thicker the material, the larger amount of the absorbed energy. As a result, a photographic film is obtained where dark color is associated with high intensity of the transmitted beam and light is associated to low intensity. The gamma radiation can penetrate up to $5 \mathrm{~cm}$ of the metal with acceptable signal of attenuation [29]. The method is commonly used to control of the permanence of the weld [28]. Radiography is also used for corrosion pits monitoring. Limitation of the methods is a fact that the material has to be available from both sides [18]. Eddy current is a technique used for monitoring of cracking and pitting corrosion of metallic materials. The method depends on the eddy current produced in the surface of the metallic material. The method is restricted to a small layer in the surface of the metal [28]. Magnetic particle inspection method is applied only to ferromagnetic materials and is based on the fact that the surface distortion imparts to a magnetic field. The tested material can be magnetized by several methods like flow an electrical current through material or using electromagnets [28]. Another possibility to control corrosion is to measure indirect changes such as hydrogen evolution which is a product of cathodic reaction. Hydrogen monitoring is applicable to oil and petrochemical industries. The monitoring is based on techniques such as hydrogen pressure or vacuum probe, electrochemical hydrogen patch probe and hydrogen fuel cell probe [29]. Water chemistry analyses can provide interesting information to corrosion monitoring program such as measurement of $\mathrm{pH}$, conductivity or dissolved oxygen [29].

Corrosion monitoring methods like weight loss measurements, linear polarization measurements or electrical sensor utilizing electrical resistance are also used in the field. However, the measurements are indirect which make it difficult to estimate real corrosion damage [25]. All used methods have to be standardized. Examples of extensive collections are the NACE (National Association of Corrosion Engineers) standards and the ASTM (American Society for Testing and Materials) standards [18]. 


\section{Laboratory methods for corrosion study}

The most widespread methods for laboratory corrosion study as well to calculate a corrosion rate (CR) are gravimetric and electrochemical (potentiometry and impedance spectroscopy) techniques, whereas scanning electron microscope (SEM), atomic force microscope (AFM) and transmission electron microscope (TEM) are used to show morphology of surface. The gravimetric method, that is, the weight loss measurements, is one of the simplest methods to carry out. A sample of tested metal, previously carefully degreased and polished is weighed and immersed in an electrolyte solution for specified time (t). After that time, the sample is taken out, sluiced, degreased and weighted. The average weight loss $(\Delta \mathrm{W})$ is calculated by following equation:

$$
\Delta \mathrm{W}=\mathrm{W}_{1}-\mathrm{W}_{2}
$$

where $W_{1}$ and $W_{2}$ is samples weight before and after immersion in electrolyte solution for $t$ time, respectively [31]. $\Delta \mathrm{W}$ is represented in grams. Based on obtained results, corrosion rate can be estimated as

$$
\mathrm{CR}=\left(\mathrm{K}^{*} \Delta \mathrm{W}\right) /\left(\mathrm{A}^{*} \mathrm{t}^{*} \mathrm{~d}\right)
$$

where $\mathrm{K}$ is a constant $\left(8.76 \times 10^{4}\right)$ which allows to represent $\mathrm{CR}$ in mm/year; $\mathrm{A}$ is the surface of the metal sample $\left(\mathrm{cm}^{2}\right)$; $t$ is the immersion time (hours); $d$ is the density of the metal $\left(\mathrm{g} / \mathrm{cm}^{3}\right)[31]$.

On the other hand, open circuit potential (OCP), named also corrosion potential ( $\left.\mathrm{E}_{\text {corr }}\right)$, linear polarization resistance (LPR) and potentiodynamic measurements (Tafel slopes) are included in potentiometric methods [32]. The measurements are conducted in standard, three electrode system such as reference (saturated calomel electrode), auxiliary (platinum electrode) and working (sample of the tested metal).

Electrodes are immersed in the electrolyte solution. After reaching an equilibrium, OCP $\left(\mathrm{E}_{\mathrm{corr}}\right)$, which is a difference in potential of microcells of the metal, is registered. At that potential, oxidation and reduction reactions occur which allows to estimate if the metal is resistant to corrosion in tested environment. The higher value of $\mathrm{E}_{\mathrm{corr}}$ the higher corrosion resistance of the metal [33]. Graphical representation of results of the potentiodynamic measurements are Tafel slopes: graphs of applied potential (E, V) versus registered current density $\left(\mathrm{i}, \mathrm{A} / \mathrm{cm}^{2}\right.$ ) (Figure 2) [34].

The graph of applied potential versus registered current density is a straight line but that behavior is not observed for measured current (black lines). Due to that, corrosion current density $\left(i_{\text {corr }}\right)$ is estimated by extrapolation of straight part of the measured current (green lines). The value of corrosion current density is equal for anodic and cathodic reactions, that is, the parameter has a direct influence on the corrosion rate [34].

The value of $\mathrm{i}_{\text {corr }}$ can also be estimated by measuring linear polarization resistance which is a quick testing technique for this method the material is polarized. The material's resistance $\left(R_{p}\right)$ is found by taking the slope of the potential versus current and the corrosion current density is calculated by using Stern-Geary Equation [35]: 


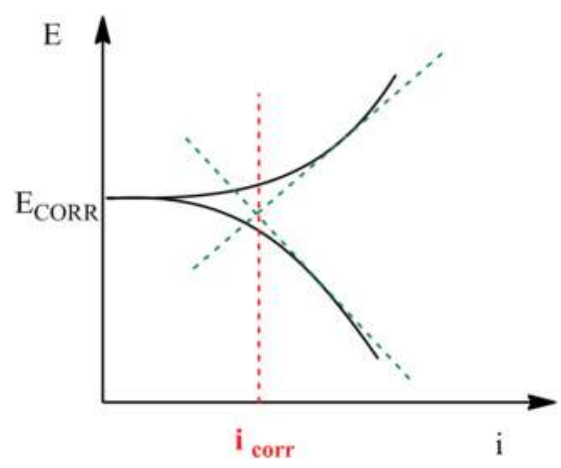

Figure 2. Tafel slopes.

$$
i_{\text {corr }}=\left(\beta_{\mathrm{a}} \beta_{\mathrm{c}} / 2.303\left(\beta_{\mathrm{a}}+\beta_{\mathrm{c}}\right)\right) / R_{p}
$$

where $\beta_{\mathrm{a}}, \beta_{\mathrm{c}}$ are slopes of anodic and cathodic of Tafel slopes, respectively [34].

Knowing the $i_{\text {corr }}$ value, corrosion rate can be estimated:

$$
\mathrm{CR}=i_{\text {corr }}{ }^{*} \mathrm{E}_{\mathrm{q}}{ }^{*} 10^{*} 3.15^{*} 10^{7} / \mathrm{F}^{*} \mathrm{~d}
$$

where $\mathrm{E}_{\mathrm{q}}$ is the equivalent mass of metal exposed to corrosion $(\mathrm{g})$; $\mathrm{F}$ is the Faraday constant $(96,500 \mathrm{C})$; $\mathrm{d}$ is the density of metal $\left(\mathrm{g} / \mathrm{cm}^{3}\right)$ and $10 \times 3.15 \times 10^{7}$ is the conversion factor used to obtain the result in $\mathrm{mm} /$ year [36].

Electrochemical impedance spectroscopy is also carried out in the standard three electrode system. After reaching equilibrium, impulse with known potential and frequency is applied. It disturbs balance of the electrochemical system. A measured quantity is impedance of the working electrode, $Z(\Omega)$, which is described by two types of impedance: real, $\operatorname{Re}(Z)$ and imaginary, $\operatorname{Im}(Z)$. The results are presented as Nyquist diagrams: a curve in $\operatorname{Re}(Z)-\operatorname{Im}(Z)$ system [34]. Analysis of obtained data consists in describing the studied system with an equivalent electrical circuit. When the processes are related to charge transfer between metal and electrolyte, then the equivalent circuit consists in: solution resistance $\left(R_{s}\right)$, charge transfer resistance $\left(\mathrm{R}_{\mathrm{ct}}\right)$ and double layer capacitance $\left(\mathrm{C}_{\mathrm{dl}}\right)$ formed at the metal:solution interface. An example of the Nyquist diagram and the equivalent circuit is presented in Figure 3.

In practice, instead of double layer capacitance, constant phase element (CPE) is used. Thanks to that, a fact that the system is not ideal capacitor to be considered. CPE is converted to $\mathrm{C}_{\mathrm{dl}}$ by following equation [37]:

$$
\mathrm{C}_{\mathrm{dl}}=\left[\left(\mathrm{CPE}^{*} \mathrm{R}_{\mathrm{ct}}\right)^{1 / \mathrm{n}}\right] / \mathrm{R}_{\mathrm{ct}}
$$

Where $\mathrm{n}$ is a chase shift which represents degree of imperfection [38]. 


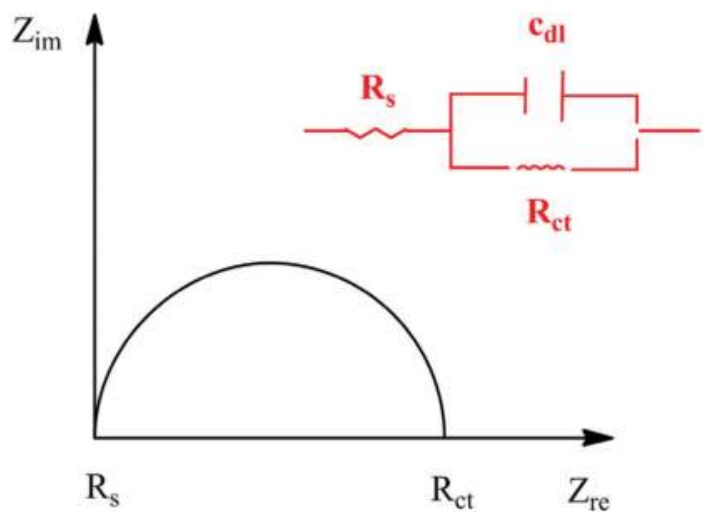

Figure 3. Nyquist diagram and equivalent circuit.

Corrosion rate is calculated from the equation:

$$
\mathrm{CR}=i_{\text {corr }}{ }^{*} \mathrm{E}_{\mathrm{q}}{ }^{*} 10^{*} 3.15^{*} 10^{7} / \mathrm{F}^{*} \mathrm{~d}
$$

Corrosion current density is calculated from Stern-Geary equation [36].

Surface morphology of the metal is examined by using microscope techniques, SEM, AFM or TEM. It allows to observe all surface defects/damage done by corrosion [39]. Very often confocal laser scanning microscope (CLSM) is used to choose the right area of the surface for further SEM/AFM/TEM examinations [37]. The mentioned methods are the most popular but there are also other possibilities to estimate corrosive damage such as analytical methods, volumetric, radiography or magnetic-powder testing. Analytical methods are based on the determination of the metal ions content in environment and qualitative and quantitative analysis of corrosion products by using mass spectrometry, absorption atomic spectrometry or spectrophotometry [31,37]. Volumetric method measures volume of evolving gas in the corrosive reaction. Radiography is based on phenomenon of radiation absorption by materials. Radiographic images are compared with the image of undamaged sample [41]. Magneticpowder testing consists in irregularity of distribution of the magnetic field in material's defects. Tested sample has to be magnetized and then magnetic particles are applied and assemble in damage. Magnetic-powder testing is applied only for ferromagnetic materials [34].

\section{Corrosion protection methods}

There are five primary methods of corrosion control: (I) material selection, (II) design, (III) cathodic protection, (IV) coatings and (V) inhibitors. The simplest method for controlling the corrosion is the selection of the structural materials that change composition, change microstructure stress and eliminate tensile stress [39, 40]. Another method is an application of rational design principles which can eliminate many corrosion problems and reduce the time and costs associated with corrosion maintenance and repair [39, 40]. Cathodic protection is an 
electrical method to reduce corrosion rate of metallic structures in electrolytes such as soil or water [42]. To achieve the protection, the impressed current cathodic protection (ICCP) system and the sacrificial anodes cathodic protection (SACP) system are used [44]. Corrosion control by anodic protection is known from the literature [43] but currently it is rarely used due to high restrictions.

Coatings, that is, the isolation of the metal from the corrosive environment is one of the most significant method of protection against corrosion. Coatings could be metallic (tin-plated steel and galvanized steel) or non-metallic (organic or inorganic). The most important are organic coatings, polymers made from epoxides, polyurethanes, polyesters, melamine formaldehyde resins, polyacrylates and phenolic polymers $[42,43]$.

Recently, many new protective coatings have been developed; they could be based on graphene [47], hybrid based on graphene oxide (GO) and reduced graphene oxide [22, 45, 46], polypyrrole [50], polyaniline/polyvinyl chloride blended [51], nano-hybrid epoxy coatings [52], bio-based polymers [53] or inorganic: siloxane based sol-gel coatings [54], silicatitaniahybrid [55] and iron aluminide coating [56]. Some of them can be used to form the superhydrophobicity surface $[48,49,54-59,61]$. The coatings can also contain anticorrosive pigments, for example, lanthanum molybdate [62] or sodium phosphomolybdate [63], or anticorrosive coating additives like multiwalled carbon nanotubes [64]. To get the best protection against corrosion as well the optimal economy coatings and cathodic protection can be complementary used [44]. Corrosion inhibitors are special group of substances or their mixtures that prevent or minimize the corrosion. Inhibitors are adsorbed on the surface of the metal and form a protective thin film $[39,62]$.

The consumption of corrosion inhibitors reached nearly $\$ 1.1$ billion in USA in 1998 and is forecasted to increase to $\$ 2.5$ billion in 2017 [66].

Inorganic corrosion inhibitors, besides the oldest one, that is, molybdate anion, belong to calcium nitrite, rare earth metals salts, zinc phosphate, chromates and lanthanide compounds. However, the most numerous class of corrosion inhibitors are organic once [67]. Many of them are surfactants with hydrophilic and hydrophobic molecular moieties [68]. The corrosion inhibitors can be introduced as protective coating [69], bio-based lubricants [67, 68] and smart coatings that are released by the action of specific stimulus (e.g. change of $\mathrm{pH}$, ionic strength or the change of electrode potential) [42, 60, 69-72].

\section{Organic corrosion inhibitors}

Organic corrosion inhibitors are widely used in industry because of their effectiveness at wide range of temperatures, compatibility with protected materials, good solubility and relatively low toxicity $[78,79]$ This is a very important issue for researchers which is confirmed by an increasing number of papers (Figure 4). These compounds act as cathodic and anodic inhibitors. Cathodic corrosion inhibitors move the corrosion potential toward lower values and inhibit or delay the reactions occurring at the cathode (oxygen reduction and hydrogen evolution). 


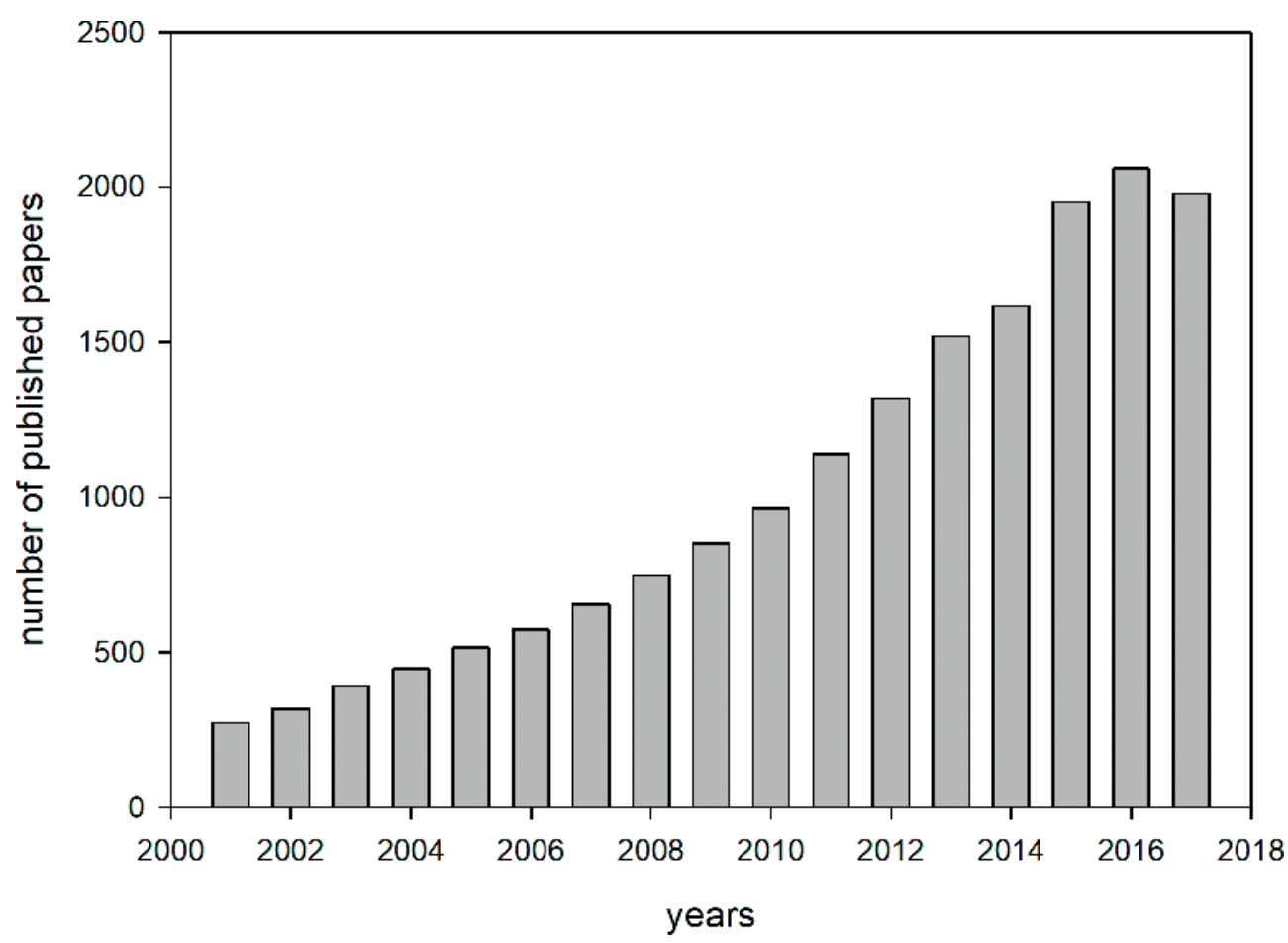

Figure 4. Number of published papers about organic corrosion inhibitors versus year of publication.

In contrast, anode corrosion inhibitors react with the metal cation to form an insoluble hydroxide, block the active sites on the metal surface and move the corrosion potential in the direction of positive values, which prevents further oxidation (dissolution) of the metal thus reducing the rate of corrosion. It is very important to use the right amount of an anode inhibitor, because insufficient concentration to cover all the active sites can lead to localized corrosion which is difficult to detect. Mixed inhibitors provide the highest protection because they affect both cathodic and anodic reactions.

The mechanism of action of organic corrosion inhibitors is based on the adsorption on the surface to form protective film which displace water from the metal surface and protect it against deteriorating. This process is not either purely physical or purely chemical adsorption. Adsorption is influenced by the chemical structure of organic inhibitors, nature and surface charge, the distribution of charge in the molecule and type of aggressive media $(\mathrm{pH}$ and/or electrode potential). The physical adsorption is based on electrostatic interaction between the charged metal surface and charged inhibitor molecule. Chemical adsorption is connected with the donor-acceptor interactions between free electron pairs and vacant, low energy d-orbital of metal (Figure 5). 


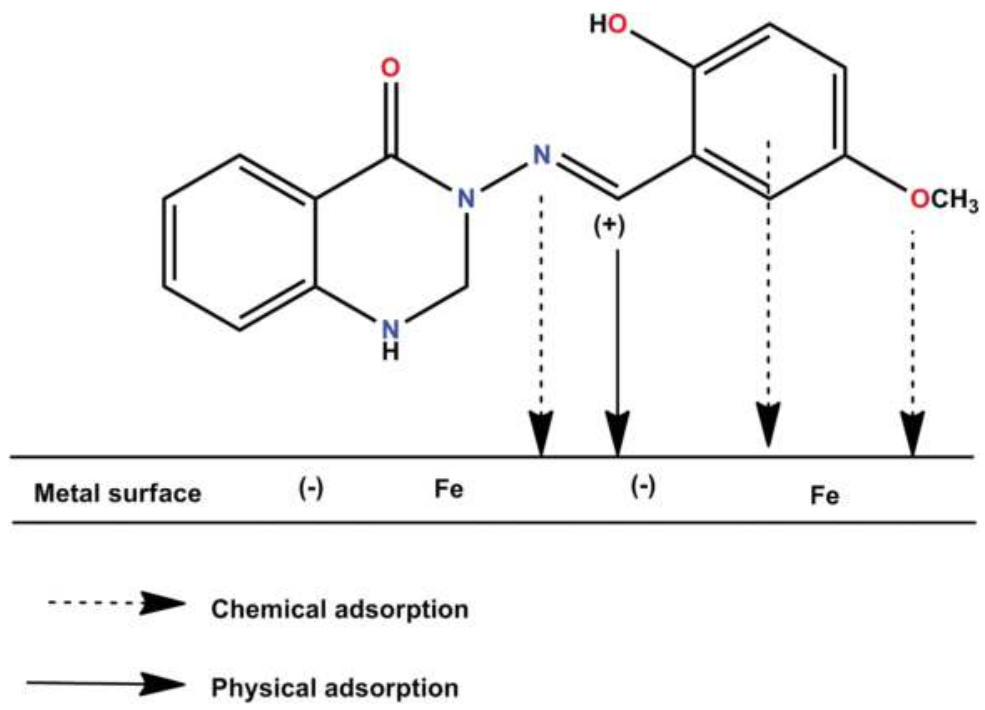

Figure 5. Schematic diagram representing the adsorption mechanism of Shiff bases on mild steel surface [82].

Effective organic corrosion inhibitors should contain heteroatoms (nitrogen, oxygen, sulfur and phosphorus) with lone electron pairs and moiety with $\pi$-electrons (aromatic rings and multiple bonds) that can interact with free orbital d metal, favoring the adsorption process [73].

The standard adsorption free energy $\left(\Delta G^{\circ}\right.$ ads $)$ gives information about type of adsorption. Values up to $-20 \mathrm{~kJ} / \mathrm{mol}$ are connected with the electrostatic interaction (physical adsorption). More negative values, below $-40 \mathrm{~kJ} / \mathrm{mol}$, correspond to chemisorption process. Negative values mean that both processes are spontaneous. Also the standard enthalpy of adsorption provides valuable information about the mechanism of corrosion inhibition. An endothermic adsorption process $\left(\Delta \mathrm{H}^{\circ}\right.$ ads $\left.>0\right)$ is attributed to chemisorptions, whereas an exothermic adsorption $\left(\Delta \mathrm{H}^{\circ}\right.$ ads $\left.<0\right)$ is connected to physical or physical/chemical adsorption process [26]. Presence of the heteroatoms with lone pair of electrons like nitrogen, oxygen, sulfur or phosphor as well $\pi$-electrons of multiple bonds or aromatic rings enhance adsorption phenomena [74]. Chemisorption involves transfer or sharing of unbounded electrons between the inhibitor molecule and the metal surface [75]. The order of corrosion inhibition is the reverse order of the electronegativity of these atoms

$$
\mathrm{P}>\mathrm{S}>\mathrm{N}>\mathrm{O}
$$

In acid environment, heteroatoms are protonated that additionally promotes the interactions between the inhibitor and the surface. The adsorption of organic corrosion inhibitors onto the surface of a corroding metal may be regarded as a substitution process between the organic compound, especially aliphatic chain in aqueous phase and water molecules adsorbed on the metal surface: 


$$
\operatorname{Org}_{(\text {sol })}+\mathrm{xH}_{2} \mathrm{O}_{(\text {ads })} \leftrightarrow \operatorname{Org}_{(\text {ads })}+\mathrm{xH}_{2} \mathrm{O}_{(\text {sol })}
$$

where Org (sol) and Org (ads) are, respectively, the organic species dissolved in the aqueous solution and adsorbed onto the metallic surface; $\mathrm{H}_{2} \mathrm{O}$ (ads) and $\mathrm{H}_{2} \mathrm{O}$ (sol) is the water molecule adsorbed onto the metallic surface and that in the bulk solution; $x$ is the size ratio representing the number of water molecules replaced by one organic adsorbate.

The aliphatic chain has an influence on the corrosion protection due to the repulsion of nonpolar hydrophobic part of inhibitor and polar medium. The hydrophobic chains form a protective layer at the metal/water interface. The size and molecular weight of organic inhibitor also have an impact on the efficiency of inhibition [76]. Larger the molecule, greater is the inhibition efficiency:

$$
\mathrm{R}_{3} \mathrm{~N}>\mathrm{R}_{2} \mathrm{NH}>\mathrm{RNH}_{2}
$$

where $\mathrm{R}$ is a hydrocarbon chain.

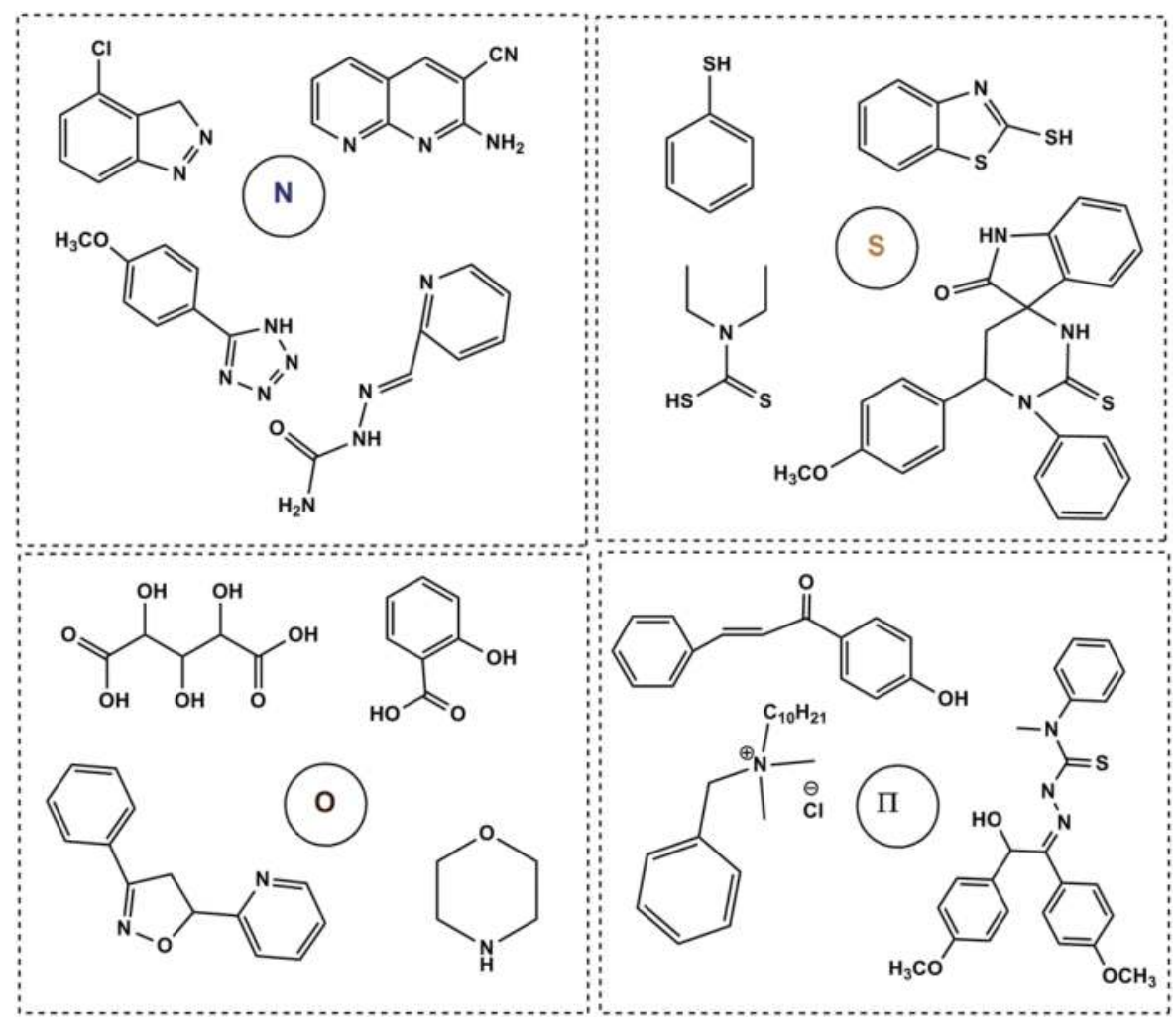

Figure 6. Nitrogen, sulfur, oxygen and $\pi$ clusters of organic corrosion inhibitors. 
Concentration of corrosion inhibitors has an important impact on the inhibitor efficiency. The corrosion rate decreases with increasing concentration of inhibitors because the adsorption of the inhibitor also increases.

\subsection{Structures of organic corrosion inhibitors}

The large number of organic corrosion inhibitors can be divided for some clusters with specific elements, like (Figure 6):

- compounds containing nitrogen: amines [77], pyridine derivatives [74, 75], quaternary ammonium salts [80], triazole derivatives [81], Schiff base [82], amino acids [64] and indazole [83],

- compounds containing nitrogen and sulfur: imidazole derivatives [84], thiadiazole derivatives and thiazole derivatives [85],

- compounds containing sulfur: thiourea derivatives [86] ans sulfonates,

- compounds containing nitrogen and oxygen: oxazol derivatives [87], phtalimides [88] and plant extracts/natural [89].

Data about material, kind of inhibitor and inhibition efficiency are summarized in Table 1.

Polymers have also a high anti-corrosion efficacy. This involves the ability to interact with many, so that surface adsorption is stronger in comparison with monomers. Polymers can be a protective coating, but they can also be used as corrosion inhibitors. For example, deoxyribonucleic acid is a biopolymer with high inhibition efficiency against steel reinforcement [94]. Similarly, natural polymer, chitosan, is used as corrosion inhibitor of copper in hydrochloric acid [95].

\begin{tabular}{|c|c|c|c|c|c|}
\hline Material & Medium & Corrosion inhibitors & $\begin{array}{l}\text { Conc. of } \\
\text { inhibitor }\end{array}$ & $\begin{array}{l}\text { Inhbition } \\
\text { efficiency (\%) }\end{array}$ & Reference \\
\hline Mild steel & $1 \mathrm{M} \mathrm{HCl}$ & $\begin{array}{l}\text { 2-(4 -nitrophenyl) } \\
\text { benzimidazole }\end{array}$ & $1 \mathrm{mM}$ & 93.7 & {$[90]$} \\
\hline Mild steel & $1 \mathrm{M} \mathrm{HCl}$ & $\begin{array}{l}\text { (6-methyl-3- } \\
\text { oxopyridazine-2-yl) } \\
\text { acetate }\end{array}$ & $10^{-1} \mathrm{mM}$ & 66.7 & [91] \\
\hline Mild steel & $1 \mathrm{M} \mathrm{HCl}$ & Shiff base & $1 \mathrm{mM}$ & 92.0 & {$[82]$} \\
\hline $\begin{array}{l}\text { Low-alloy steel } \\
\text { specimen }\end{array}$ & $1 \% \mathrm{NaCl}$ & L-cysteine & 400 ppm & 65.7 & {$[64]$} \\
\hline $\begin{array}{l}\text { Carbon steel } \\
\text { (API N80) }\end{array}$ & $\begin{array}{l}1.65 \mathrm{wt} \% \mathrm{NaCl} \text { con. } \\
1 \mathrm{~g} / \mathrm{L} \text { acetic acid }\end{array}$ & Imidazoline & $0.1 \mathrm{~g} / \mathrm{L}$ & 99.3 & {$[84]$} \\
\hline Copper & $3 \% \mathrm{NaCl}$ & $\begin{array}{l}\text { N-decyl-3-amino- } \\
\text { 1,2,4-triazole }\end{array}$ & $10^{-3} \mathrm{M}$ & 99.2 & [92] \\
\hline Tin & $0.5 \mathrm{M} \mathrm{HCl}$ & Adenosine & $10^{-3} \mathrm{M}$ & 73.0 & {$[93]$} \\
\hline Indium & $0.5 \mathrm{M} \mathrm{HCl}$ & Adenosine & $10^{-3} \mathrm{M}$ & 72.0 & [93] \\
\hline $\begin{array}{l}\text { Tin-Indium Alloy } \\
\text { (5\%Indium) }\end{array}$ & $0.5 \mathrm{M} \mathrm{HCl}$ & Adenosine & $10^{-3} \mathrm{M}$ & 73.0 & [93] \\
\hline
\end{tabular}

Table 1. Data about material, kind of inhibitor and inhibition efficiency. 


\section{Quaternary ammonium salts as corrosion inhibitors}

Due to the presence of positively charged nitrogen atom and the amphiphilic structure, quaternary ammonium salts are the center of interest for using them as highly effective corrosion inhibitors [96-100]. A special attention is devoted to new generation of quaternary ammonium salts-gemini surfactants. These compounds contain two hydrophilic head groups and two hydrophobic tails connected by a spacer at the head groups or closed to them. The spacer can have different structure; it can be rigid or flexible. It can also be hydrophobic or hydrophilic. The neutral charge of the molecule is retained by the presence of organic or inorganic anions. The gemini alkylammonium salts possess a very low critical micelle concentrations $(\mathrm{cmc})$, which is up to hundred times lower than $\mathrm{cmc}^{\prime} \mathrm{s}$ of corresponding monomeric surfactants. Gemini surfactants also have a larger molecular area in comparison to monomeric analogs which cause them to act more efficiently as corrosion inhibitors [80, 101-110]. Dimeric surfactant 1,4-tetramethylene-bis( $N$-dodecyl- $N, N$-dimethylammonium bromide) (12-4-12) is more efficient in decreasing corrosion rate of carbon steel in $1 \mathrm{M} \mathrm{HCl}$ than its monomeric analogue $\mathrm{N}$-dodecyl- $\mathrm{N}, \mathrm{N}, \mathrm{N}$-trimethylammonium bromide (DTAB). The relationships of concentration and corrosion rate for both surfactants are presented in Figure 7.

Resistance of the carbon steel in a system-containing dimeric surfactant is much higher in comparison to blank solution $(1 \mathrm{M} \mathrm{HCl})$ or to solution-containing monomeric surfactant (Table 2). It means that metal is less susceptible to corrosion [111].

Inhibition efficiency (IE\%) is affected not only by number of positively charged nitrogen atoms but also depends on the length of alkyl chain. Longer the alkyl chain higher is the inhibition efficiency [97, 105] (Table 3).

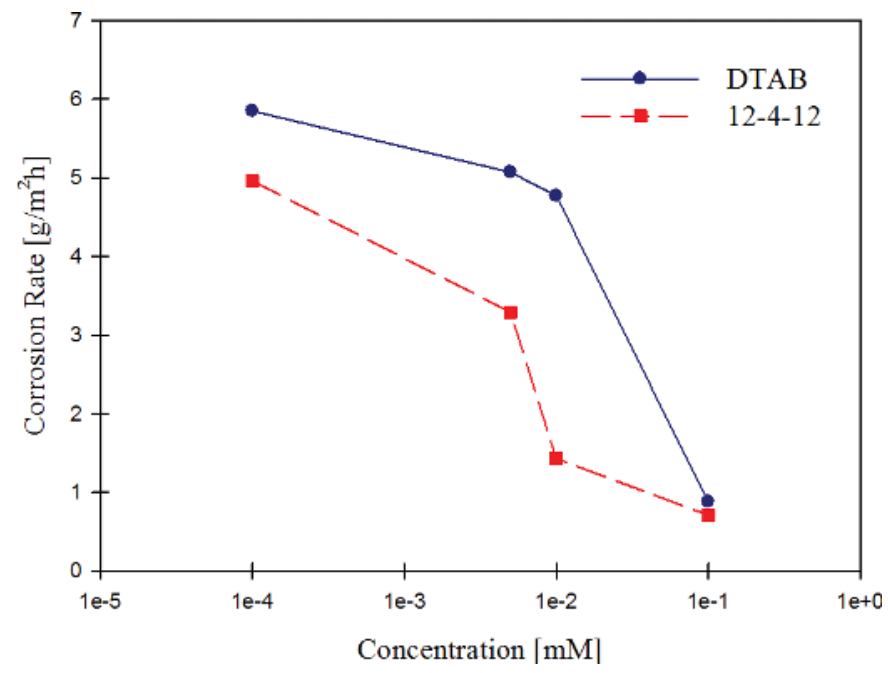

Figure 7. Relationship between corrosion rate of carbon steel and concentrations of surfactants. 


\begin{tabular}{lll}
\hline & Concentration of surfactant $(\mathbf{m M})$ & $\mathrm{R}\left(\Omega \mathrm{cm}^{2}\right)$ \\
\hline Blank & - & 43 \\
DTAB & 0.05 & 159 \\
$12-4-12$ & 0.001 & 364 \\
\hline
\end{tabular}

Table 2. Resistance of the carbon steel immersed in solution without and with cationic inhibitors.

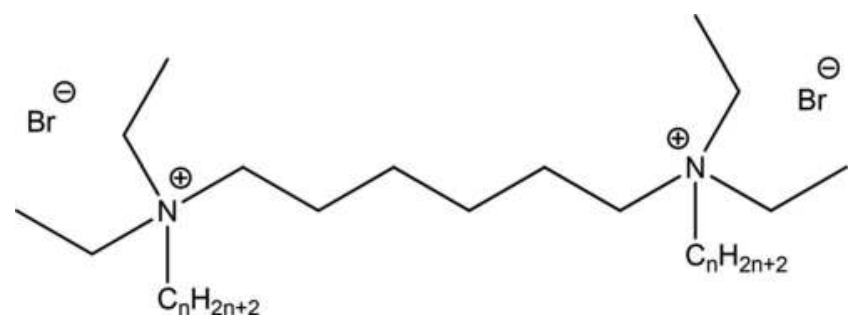

\begin{tabular}{ll}
$\mathbf{n}$ & IE (\%) \\
\hline 10 & 93.7 \\
12 & 95.3 \\
14 & 96.5 \\
16 & 98.2 \\
\hline
\end{tabular}

Table 3. Inhibition efficiency of dimeric surfactants for aluminum in $1 \mathrm{M} \mathrm{HCl}$; concentration of surfactants: $1 \mathrm{mM}$ [112].

The same correlation is observed in the spacer length. Longer the spacer, higher is the inhibition efficacy. For gemini surfactant $\left(\left(\mathrm{C}_{12} \mathrm{H}_{25}\right)_{3} \mathrm{~N}^{+}-\mathrm{s}-\mathrm{N}^{+}\left(\mathrm{C}_{12} \mathrm{H}_{25}\right)_{3}\right)$ with two methylene groups as spacer (s) inhibition efficiency is $89 \%$ whereas IE is $93 \%$ for six methylene units at concentration $5 \mathrm{mM}$ [109].

Additional heteroatoms or $\pi$ electrons also favor adsorption onto the metal surface [113]. The order of the effective action increases with decreasing the electronegativity of the heteroatom: $\mathrm{O}<\mathrm{N}<\mathrm{S}<\mathrm{P}$ [114]. Replacement of isopropyl group to hydroxyethyl or benzyl group leads to the increase of the inhibition efficiency from 95 to 96 or $97 \%$, respectively (Table 4) [115]. Oxygen is a source of two unbonded electron pairs whereas benzene ring is a source of three pairs of $\pi$ electrons, which can interact with free $d$ orbitals of the metal.

Increasing the number of heteroatoms also affects the inhibition efficiency (Figure 8) where 12-6-12 is 1,6-hexamethylene-bis(N-dodecyl- $N, N$-dimethylammonium) dibromide; G6-MOH-12 is (1,6-hexamethylene-bis( $\mathrm{N}$-dodecyl- $\mathrm{N}$-hydroxyethyl- $\mathrm{N}$-methylammonium) dibromide; $12-\mathrm{MOH}$ $\mathrm{O}-\mathrm{MOH}-12$ is 3-oxa-1,5-pentamethylene-bis( $\mathrm{N}$-dodecyl- $\mathrm{N}$-hydroxy-ethyl- $\mathrm{N}$-methyl-ammonium) dichloride [116].

The plots in Figure 8 present a semicircular shape with a diameter corresponding to the corrosion resistance (large diameter and higher resistance). The stainless steel impedance response in 


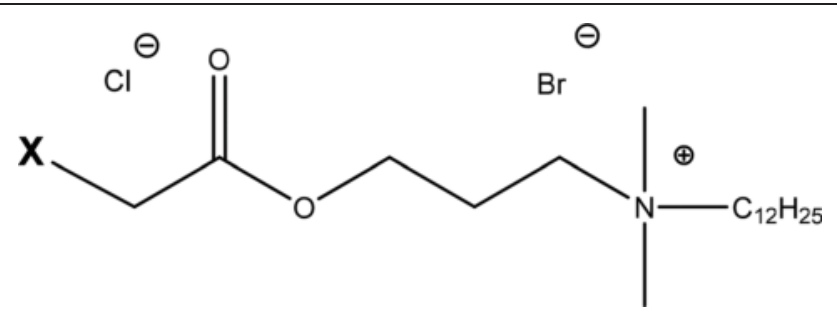

\begin{tabular}{ll}
$\mathbf{X}$ & Inhibition efficiency (\%) \\
\hline$\left(\mathrm{CH}_{3}\right)_{2} \mathrm{CHN}^{+}\left(\mathrm{CH}_{3}\right)_{2}$ & 95.43 \\
$\mathrm{OHCH}_{2} \mathrm{CH}_{2} \mathrm{~N}^{+}\left(\mathrm{CH}_{3}\right)_{2}$ & 96.24 \\
$\mathrm{PhN}^{+}\left(\mathrm{CH}_{2} \mathrm{CH}_{3}\right)_{2}$ & 97.19 \\
\hline
\end{tabular}

Table 4. Influence of the presence of heteroatoms and $\pi$ electrons on inhibition efficiency of steel in $1 \mathrm{M} \mathrm{HCl}$.

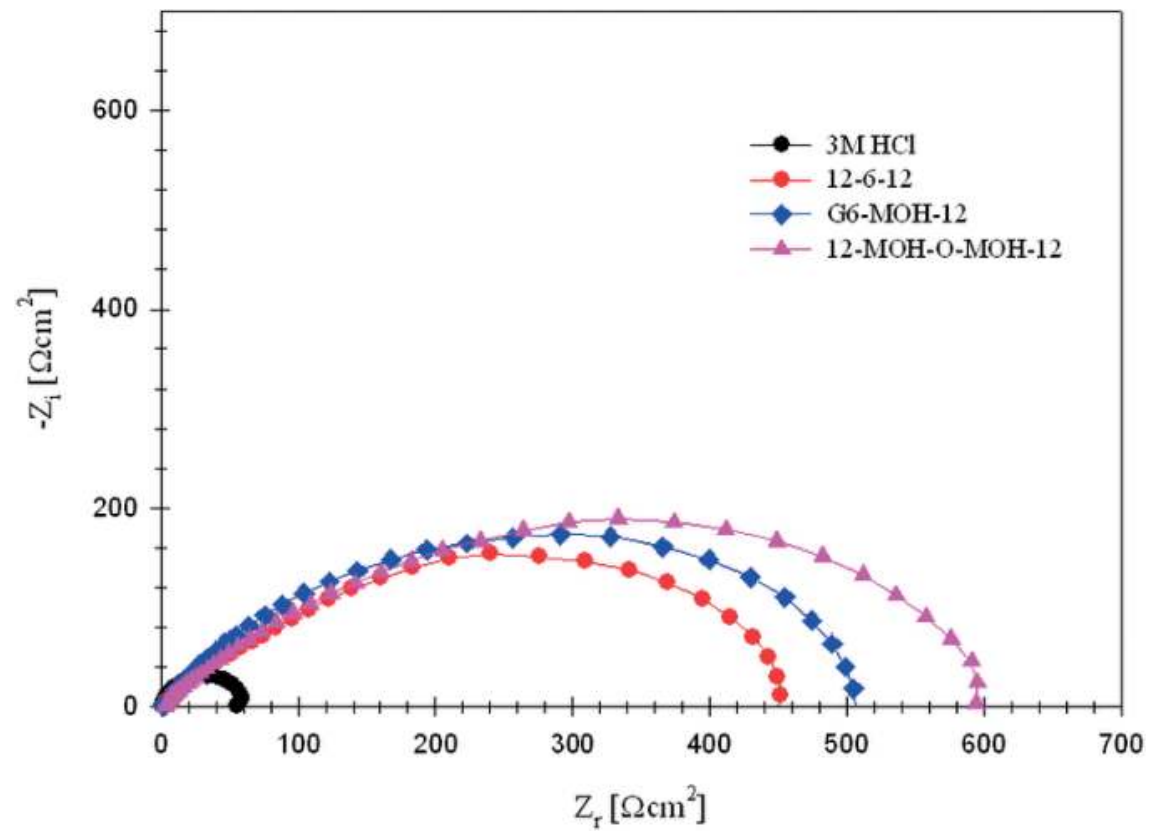

Figure 8. Structure of the gemini surfactants and Nyquist plots for stainless steel in $3 \mathrm{M} \mathrm{HCl}$ in the presence and absence of the synthesized inhibitors (naturally aerated, 7 days of immersion).

the blank solution (black) shows a smaller diameter compared to the diameters of the plots for both gemini surfactants, the latter indicating higher resistance, that is, lower corrosion rate. The diameter is the biggest for surfactants functionalized with three oxygen atoms (12-MOH-O$\mathrm{MOH}-12$ ) [116]. Some of gemini surfactants, which are already commercially used, are a part of 


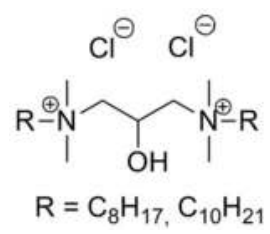

Figure 9. Structure of one commercially used inhibitor.

special compositions which are based on synergistic effect in order to lower the concentrations used [30, 110-112]. Some gemini surfactants are a part of patent about multifunctional corrosion inhibitors for iron alloys (tanks transporting oil and liquid fuel) which are subjected to acidic pollution, sulfur compounds, water, oxygen as well as calcium and magnesium cations [120]. Another patent is about using gemini surfactants as corrosion inhibitors of metallic materials which are used for gas and oil extraction [121]. The inhibitors contain heteroatoms and $\pi$ electrons, their efficiency is higher than $90 \%$. One inhibitor's structure is presented in Figure 9 [120].

One of the interesting organic corrosion inhibitors are ionic liquids (ILs) as potentially green chemicals. Amidation of chitosan subsequently quaternized with oleic acid and p-toluene sulfonic acid gave new ionic liquid. The corrosion inhibition of the prepared polymeric ionic liquid on steel in acidic medium was investigated by using different electrochemical techniques [122].

\section{Biocorrosion}

Microbially induced corrosion (MIC) is one of the fundamental problems in marine industry, pulp and paper industry, natural gas transmission, industrial water transmission, metalworking and chemical process industries. This kind of corrosion is also called as biocorrosion, bacterial corrosion, microbial corrosion is deterioration of metal or non-metal materials as a result of the metabolic activity of microorganisms [116, 117]. Biocorosion is mostly a result of the interaction of mechanical, physical, chemical and/or biological factors. Wind, water, particles of dust, pollution atmosphere and water, and, in the case of stone materials, action light and temperature changes cause damage to materials, allowing penetration moisture and colonization of microorganisms on their surface. This leads to the uprising biofilm, a biologically active layer of various types of microorganisms as well as mucus being the product of their metabolic activity. Biofilm creates very good environment for growing microorganism, and increase rate of corrosion even to 10,000 times. The key to avoid this problem is understanding the dynamics of microbes $[118,119]$.

\subsection{Microorganism and environment}

Prerequisites for microbial-induced corrosion are the presence of microorganisms. If the corrosion is influenced by their activity, further requirements are (a) an energy source, (b) a carbon 
source, (c) an electron donator and (d) water. The kinetics of biocorrosion is strongly influenced by the concentration of oxygen, presence of salts, $\mathrm{pH}$ value, redox potential and conductivity. The living bacteria produce extracellular polymeric substances (EPS) and form biofilms on the metal surface. Biofilms are characterized by strong heterogeneity [120,121]. Biofilm consists of bacterial cells and extracellular polymeric substances (mixture of polysaccharides, proteins, nucleic acids and fats) which facilitate the attachment of bacterial cells to the surface. The biofilm also includes inorganic sludge from water and/or corrosion products [122, 123]. The most common methods to observe biocorrosion effects are scanning electron microscope (SEM) and confocal laser scanning microscope (CLSM) [128] as well as X-ray photoelectron spectroscopy [124-126] and time of flight-secondary ion mass spectroscopy (ToF-SIMS) [129].

Bacteria involved in corrosion can be divided into following groups:

Sulfate-reducing bacteria ( $S R B$ ) are anaerobic microorganisms that can obtain energy by oxidizing organic compounds or molecular hydrogen $\left(\mathrm{H}_{2}\right)$ while reducing sulfate $\left(\mathrm{SO}_{4}{ }^{2-}\right)$ to hydrogen sulfide $\left(\mathrm{H}_{2} \mathrm{~S}\right)$. In a sense, these organisms "breathe" sulfate rather than oxygen in a form of anaerobic respiration $[20,21]$. Sea water is a primary source of sulfate-reducing bacteria (SRB) (Figure 10).

Metal-reducing bacteria (MRB) affects the corrosion of iron and its alloys by dissolving the passive film on the surface of the metal or by transformation of the sediment to a less stable reduced form that does not inhibit corrosion process. Included in this group are the bacteria of Pseudomonas and Shewanella have the ability to reduce iron oxide and manganese oxides whereby the speed reduction depends on the type of sediment [130, 133].

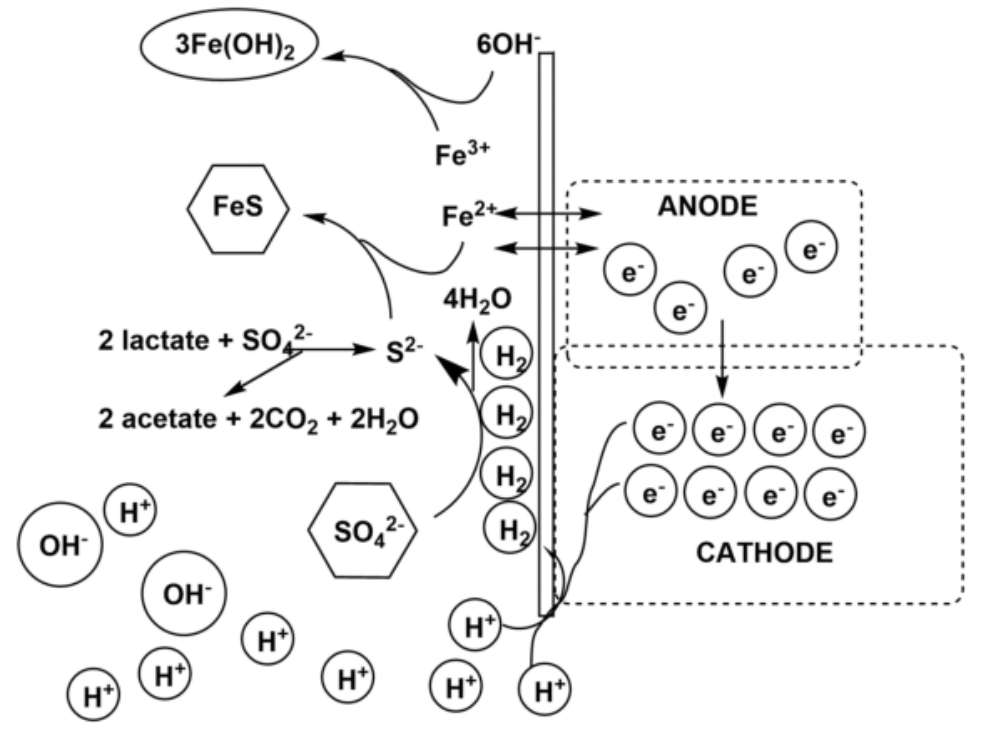

Figure 10. Mechanism of action SRB. 
Metal-depositing bacteria (MDB) - Siderocapsa, Gallionella, Leptothrix, Sphaerotilus, Crenothrix and Clonothrix are involved in the biotransformation of iron oxide and manganese. Iron-depositing bacteria (e.g. Gallionella and Leptothrix) gain energy by oxidizing Fe (II) ions (dissolved or bound in sediments) to Fe (III). All these types of bacteria have the ability to oxidize Mn (II) to $\mathrm{Mn}$ (IV) with the precipitation of manganese dioxide that occurs in the rapid filter beds. Filamentous bacteria are associated with the formation of pitting corrosion [21].

Hydrogen sulfide-producing bacteria (SPB) are bacteria producing a large amount of extracellular polymeric substances (EPS) during the development of biofilm (e.g. Clostridium, Flavobacterium and Desulfovibrio) their role in the corrosion process consists in covering the metal surface with a EPS layer facilitating the attachment and multiplication of others bacteria [21].

Acid-producing bacteria $(A P B)$ are bacteria that secrete inorganic and organic acids as products by-pass metabolism while simple organic acids (acetic, formic and lactic) are metabolites of bacteria heterotrophic [21].

\subsection{Biocorrosion inhibitors}

Methods to significantly slow have concern on inhibition of the growth of microorganisms and modification of the environment in which the corrosion process takes place. The basic steps to prevent and control biocorrosion are (i) cleaning procedures; (ii) microbiocides; (iii) coatings and (iv) cathodic protection [65].

Obviously it is not easy to stop process of growing bacteria with one compounds. Because these kind of species should have antimicrobial activity and also should be corrosion inhibitors. Example of that kind of multifunctional compounds are gemini surfactants [127, 128]. Biocidal activities of the synthesized surfactants were achieved by dropping the redox potential and confirmed preventing sulfide production in the reactor's bulk phase. This means that all sulfidogenic bacteria are active in the reactor's bulk phase and on the metal surface. Labena et al. describe potential biocorrosion inhibitors that contain quaternary ammonium atom (Figure 11) [135].

Quite new approach is using surface modification technologies such as short anti-biofilm peptides applying by immobilization method [136] also using small lipopeptides [137]. Using of coatings based on on silicone and epoxy resins are also method to protection against biocorrosion.

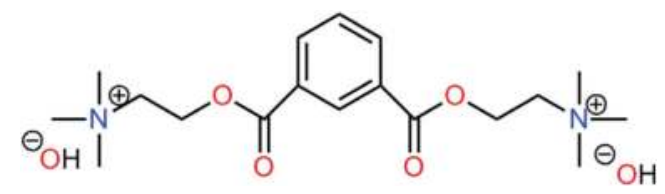

Figure 11. Structure of potential biocorrosion inhibitors. 


\section{Designing organic corrosion inhibitors}

Quantum chemical methods are useful for designing new, effective organic corrosion inhibitors as they relate electron structure of the compounds to their reactivity. Every year density functional theory (DFT) is more often applied for predicting a theoretical ability to inhibit corrosion process according to some quantum chemical parameters: energy of the highest occupied molecular orbital $\left(\mathrm{E}_{\mathrm{HOMO}}\right)$, energy of the lowest unoccupied molecular orbital $\left(E_{\text {LUMO }}\right)$, gap energy $(\Delta E)$, chemical hardness $(\eta)$, softness $(\sigma)$, ionization potential $\left(I_{P}\right)$ and electron affinity $\left(\mathrm{E}_{\mathrm{A}}\right)$, electronegativity $(\chi)$ and fraction of electron transferred $(\Delta \mathrm{N})[94,99,131$, 138]. The energy of the highest occupied molecular orbital (HOMO) is associated with the ability of a molecule to donate electrons to the free $d$ orbital of a metal. Compounds with higher $\mathrm{E}_{\mathrm{HOMO}}$ are more capable of donating electrons. The energy of the lowest unoccupied molecular orbital (LUMO) is related to the ability to accept electrons from the metal. Lower values indicate higher tendency of accepting electrons. Moreover, positive values are connected with chemisorption, whereas negative values with physisorption [94, 132]. Another important parameter is energy gap:

$$
\Delta \mathrm{E}=\mathrm{E}_{\mathrm{LUMO}}-\mathrm{E}_{\mathrm{HOMO}}
$$

The lower $\Delta \mathrm{E}$, the more reactive molecule, is related to better adsorption of inhibitor's molecules onto the metal surface $[133,134]$. The dipole moment $(\mu)$ is also an important parameter which gives information about polarity in a bond. Corrosion inhibition efficiency increases with increasing the value of $\mu$, due to the stronger dipole-dipole interactions with the metal surface which results in stronger adsorption and efficient corrosion inhibition [140]. Chemical hardness $(\eta)$ and softness $(\sigma)$ provide information about the resistance of a molecule to charge transfer and about the capacity of a molecule to receive electrons. They are calculated according to the equations:

$$
\begin{gathered}
\eta=-1 / 2\left(E_{\text {HOMO }}-E_{\text {LUMO }}\right) \\
\sigma=1 / \eta
\end{gathered}
$$

The higher $\sigma$ value suggests softer nature of the molecule and greater tendency to donate electrons to the metal [101]. Energy of HOMO and LUMO orbitals can be used for calculating ionization potential $\left(\mathrm{I}_{\mathrm{P}}\right)$ and electron affinity $\left(\mathrm{E}_{\mathrm{A}}\right)$ by the following equations:

$$
\begin{aligned}
& \mathrm{I}_{\mathrm{P}}=-\mathrm{E}_{\text {HOMO }} \\
& \mathrm{E}_{\mathrm{A}}=-\mathrm{E}_{\mathrm{LUMO}}
\end{aligned}
$$

The calculated values are used for estimating the electronegativity $(\chi)[141]$ :

$$
\chi=\left(\mathrm{I}_{\mathrm{P}}+\mathrm{E}_{\mathrm{A}}\right) / 2
$$




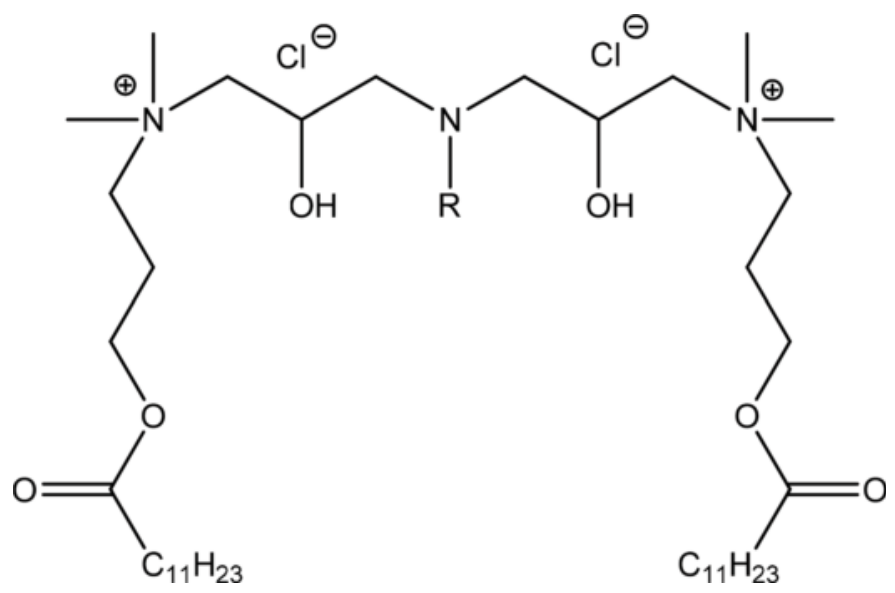

\begin{tabular}{lllllll}
\hline $\mathbf{R}$ & IE (\%) & $\mathbf{E}_{\text {номо }}(\mathrm{eV})$ & $\mathrm{E}_{\text {Lumo }}(\mathrm{eV})$ & $\Delta \mathrm{E}(\mathrm{eV})$ & $\mu(\mathrm{De})$ & $\Delta \mathbf{N}$ \\
\hline $\mathrm{C}_{4} \mathrm{H}_{9}$ & 79.86 & -4.03 & 0.86 & 4.89 & 2.16 & 1.11 \\
$\mathrm{C}_{6} \mathrm{H}_{13}$ & 79.49 & -2.10 & 0.83 & 2.93 & 5.45 & 2.17 \\
$\mathrm{C}_{8} \mathrm{H}_{17}$ & 81.32 & -1.43 & 0.73 & 2.16 & 6.42 & 3.08 \\
\hline
\end{tabular}

Table 5. Electron parameters and IE\% for the gemini surfactants.

High value of $\chi$ suggests strong ability to attract electrons from the metal which leads to greater interactions and higher corrosion protection. The last parameter which is calculated is the fraction of electron transferred $(\Delta \mathrm{N})$ :

$$
\Delta \mathrm{N}=\chi_{\mathrm{Fe}}-\chi_{\mathrm{inh}} / 2\left(\eta_{\mathrm{Fe}}-\eta_{\mathrm{inh}}\right)
$$

where $\chi_{\mathrm{Fe}}$ equals $7 \mathrm{eV}$ and $\eta_{\mathrm{Fe}}=0$ [101]. If $\Delta \mathrm{N}>0$, electrons are transferred from the molecule to the metal and if $\Delta \mathrm{N}<0$, from the metal to the molecule. For all tested gemini surfactants, the values of the fraction of electron transferred are negative indicating transfer from the metal to the molecules. Some quantum parameters for gemini surfactants and corrosion inhibition efficiency (IE\%) of carbon steel are presented in Table 5 [139].

According to the presented results, elongating the alkyl chain $(\mathrm{R})$ leads to increasing corrosion inhibition efficiency from 79.86 to $81.32 \%$. Based on the electron parameters, all values of $\mathrm{E}_{\mathrm{LUMO}}$ are negative, which are associated with physisorption. The lowest value of $\mathrm{E}_{\mathrm{LUMO}}$ and the highest value of $\mathrm{E}_{\mathrm{HOMO}}$ were noticed for a surfactant with octyl group, as well as the lowest $\Delta \mathrm{E}$ and the highest dipole moment. The electron parameters suggest the compound with octyl group should be the most efficient inhibitor of the tested group. This observation is in agreement with experimental results (IE\%). The values of $\Delta \mathrm{N}$ which are higher than 0 indicate that electrons are transferred from inhibitor to free d orbital of the metal. 


\section{Summary}

Organic corrosion inhibitors with heteroatoms and $\pi$-electron moieties are very efficient compounds to fight corrosion. The reviewed literature data clearly indicate that a new way to inhibit deterioration processes can be multifunctional gemini surfactants. Gemini alkylammonium surfactants with the highest corrosion inhibition efficacy can be synthesized according to prediction by theoretical calculations structures. These organic corrosion inhibitors can be also immobilized and used as biocorrosion inhibitors.

\section{Acknowledgements}

The work has been supported by the National Centre of Research and Development (Poland TANGO1/266340/NCBR/2015).

\section{Author details}

Bogumił Eugeniusz Brycki*, Iwona H. Kowalczyk, Adrianna Szulc, Olga Kaczerewska and Marta Pakiet

*Address all correspondence to: brycki@amu.edu.pl

Faculty of Chemistry, Laboratory of Microbiocides Chemistry, Adam Mickiewicz University, Poznan, Poland

\section{References}

[1] Raja PB, Ismail M, Ghoreishiamiri S, Mirza J, Ismail MC, Kakooei S, et al. Reviews on corrosion inhibitors: A short view. Chemical Engineering Communications. 2016 Sep; 203(9):1145-1156

[2] Shah AA, Hasan F, Hameed A, Ahmed S. Biological degradation of plastics: A comprehensive review. Biotechnology Advances. 2008 May;26(3):246-265

[3] Franz H. Durability and corrosion of silicate glass surfaces. Journal of Non-Crystalline Solids. 1980;42(1-3):529-534

[4] Melcher M, Wiesinger R, Schreiner M. Degradation of glass Artifacts: Application of modern surface analytical techniques. Accounts of Chemical Research. 2010 Jun 15;43(6): 916-926

[5] Kong L, Zhang B, Fang J. Study on the applicability of bactericides to prevent concrete microbial corrosion. Construction and Building Materials. 2017 Sep;149:1-8 
[6] Eriksson K-EL, Blanchette RA, Ander P. In: Timell TE, editor. Microbial and Enzymatic Degradation of Wood and Wood Components. Berlin, Heidelberg: Springer Berlin Heidelberg; 1990. Springer Series in Wood Science

[7] Weslien J, Djupström LB, Schroeder M, Widenfalk O. Long-term priority effects among insects and fungi colonizing decaying wood: Species interactions during wood decay. The Journal of Animal Ecology. 2011 Nov;80(6):1155-1162

[8] Ulyshen MD. Interacting effects of insects and flooding on wood decomposition. Shaw P, editor. PLoS One. 2014 Jul 10;9(7):e101867

[9] Blanchette RA, Nilsson T, Daniel G, Abad A. Biological degradation of wood. In: Rowell RM, Barbour RJ, editors. Archeological Wood: Properties, Chemistry and Preservation. Washington, USA: American Chemical Society; 1989. pp. 141-174

[10] Forrest W. Building Materials Evaluation Handbook. New York: Springer Verlag; 2012

[11] Sterflinger K, Piñar G. Microbial deterioration of cultural heritage and works of art Tilting at windmills? Applied Microbiology and Biotechnology. 2013 Nov;97(22):9637-9646

[12] ASTM International. ASTM G15-02. Standard Terminology Relating to Corrosion and Corrosion Testing. West Conshohocken: ASTM International; 2002

[13] ISO 8044:2015. Corrosion of metals and alloys - Basic terms and definitions. 8044:2015; 2015

[14] Koch G. Cost of corrosion. In: Trends in Oil and Gas Corrosion Research and Technologies. Kidlington: Elsevier; 2017. pp. 3-30

[15] Hou B, Li X, Ma X, Du C, Zhang D, Zheng M, et al. The cost of corrosion in China. npj Materials Degradation. 2017 Dec;1(1)

[16] Stewart MG, Wang X, Nguyen MN. Climate change adaptation for corrosion control of concrete infrastructure. Structural Safety. 2012 Mar;35:29-39

[17] McCafferty E. Introduction to Corrosion Science. London: Springer; 2010. p. 575

[18] Bardal E. Corrosion and Protection. London: Springer; 2004. p. 315

[19] Sastri VS. Challenges in Corrosion; Costs, Causes, Consequences, and Control. New Jersey: John Wiley \& Sons Inc.; 2015. p. 408

[20] Xu D, Li Y, Gu T. Mechanistic modeling of biocorrosion caused by biofilms of sulfate reducing bacteria and acid producing bacteria. Bioelectrochemistry. 2016 Aug;110:52-58

[21] Liengen T. Understanding Biocorrosion: Fundamentals and Applications. Boston: Elsevier; 2014

[22] Kostakioti M, Hadjifrangiskou M, Hultgren SJ. Bacterial biofilms: Development, dispersal, and therapeutic strategies in the Dawn of the Postantibiotic era. Cold Spring Harbor Perspectives in Medicine. 2013 Apr 1;3(4):a010306-a010306 
[23] Costertion JW, Stewart P, Greenberg E. Bacterial biofilms: A common cause of persistnet infections. Microbes, Immunity and Disease. 1999;284AD:1318-1322

[24] ISO/TR 16203: 2016. Corrosion of metals and alloys - Guidelines for the selection of methods for particle-free erosion corrosion testing in flowing liquids. 16203; 2016

[25] Dong B, Fang G, Liu Y, Dong P, Zhang J, Xing F, et al. Monitoring reinforcement corrosion and corrosion-induced cracking by X-ray microcomputed tomography method. Cement and Concrete Research. 2017 Oct;100:311-321

[26] Sastri VS. Green Corrosion Inhibitors: Theory and Practice. Hoboken, N.J: Wiley; 2011. p. 310. (Wiley series in corrosion)

[27] Salujaa A, Costainb J, Van der Ledenc E. Non-intrusive online corrosion monitoring. In: NDE2009. Tiruchirappalli, India: National Seminar \& Exhibition on Non-Destructive Evaluation; 2009

[28] Bardal E, Drugli JM. Corrosion detection and diagnosis. In: Materials Science and Engineering. Oxford: EOLSS Publications; 2009. pp. 144-164

[29] Roberge PR. Corrosion Inspection and Monitoring. Hoboken, N.J: Wiley-Interscience; 2007. p. 383. (Wiley series in corrosion)

[30] Yang L, Yang TT, Zhou YC, Wei YG, RT W, Wang NG. Acoustic emission monitoring and damage mode discrimination of APS thermal barrier coatings under high temperature CMAS corrosion. Surface and Coating Technology. 2016 Oct;304:272-282

[31] ASTM International. ASTM G31-72. Standard Practice for Labolatory Immersion Corrosion Testing of Metals. West Conshohocken: ASTM International; 1999

[32] ASTM International. ASTM G59. Standard Test Method for Conducting Potentiodynamic Polarization Resistance Measurements. West Conshohocken: ASTM International; 2002

[33] Migahed MA, Hegazy MA, Al-Sabagh AM. Synergistic inhibition effect between Cu2+ and cationic gemini surfactant on the corrosion of downhole tubing steel during secondary oil recovery of old wells. Corrosion Science. 2012 Aug;61:10-18

[34] Sastri VS, Ghali E, Elboujdaini M. Corrosion Prevention and Protection; Practical Solutions. England: John Wiley \& Sons Ltd.; 2007

[35] Perez N. Electrochemistry and Corrosion Science. Cham: Springer International Publishing; 2016

[36] Dehdab M, Yavari Z, Darijani M, Bargahi A. The inhibition of carbon-steel corrosion in seawater by streptomycin and tetracycline antibiotics: An experimental and theoretical study. Desalination. 2016 Dec;400:7-17

[37] Leiva-García R, Fernandes JCS, Muñoz-Portero MJ, García-Antón J. Study of the sensitisation process of a duplex stainless steel (UNS 1.4462) by means of confocal microscopy and localised electrochemical techniques. Corrosion Science. 2015 May;94:327-341 
[38] Hegazy MA, Rashwan SM, Kamel MM, El Kotb MS. Synthesis, surface properties and inhibition behavior of novel cationic gemini surfactant for corrosion of carbon steel tubes in acidic solution. Journal of Molecular Liquids. 2015 Nov;211:126-134

[39] Yadav DK, Maiti B, Quraishi MA. Electrochemical and quantum chemical studies of 3,4dihydropyrimidin-2 $(1 \mathrm{H})$-ones as corrosion inhibitors for mild steel in hydrochloric acid solution. Corrosion Science. 2010 Nov;52(11):3586-3598

[40] Joseph LA, Israel OK, Edet EJ, Ekwumemgbo PA. Determination of metal ions released by stainless steel arch bar into bio-fluids. Bulletin of the Chemical Society of Ethiopia. 2009;23(1)

[41] Michel A, Pease BJ, Geiker MR, Stang H, Olesen JF. Monitoring reinforcement corrosion and corrosion-induced cracking using non-destructive $x$-ray attenuation measurements. Cement and Concrete Research. 2011 Nov;41(11):1085-1094

[42] Davis JR. Corrosion: Understanding the Basics. Material Park, Ohio: ASTM International; 2000

[43] Salas BV, Wiener MS, Stoytcheva M, Zlatev R, Beltran MC. Corrosion in the food industry and its control. In: Food Industrial Processes-Methods and Equipment. Rijeka: InTech; 2012

[44] Tezdogan T, Demirel YK. An overview of marine corrosion protection with a focus on cathodic protection and coatings. Brodogradnja: Teorija i praksa brodogradnje i pomorske tehnike. 2014;65(2):49-59

[45] Fernández-Solis CD, Vimalanandan A, Altin A, Mondragón-Ochoa JS, Kreth K, Keil P, et al. Fundamentals of electrochemistry, corrosion and corrosion protection. In: Lang P, Liu Y, editors. Soft Matter at Aqueous Interfaces [Internet]. Cham: Springer International Publishing; 2016 ; [cited 2017 Oct 16]. pp. 29-70 Available from: http://link.springer.com/ 10.1007/978-3-319-24502-7_2

[46] Grundmeier G, Schmidt W, Stratmann M. Corrosion protection by organic coatings: Electrochemical mechanism and novel methods of investigation. Electrochimica Acta. 2000;45(15):2515-2533

[47] Prasai D, Tuberquia JC, Harl RR, Jennings GK, Bolotin KI. Graphene: Corrosioninhibiting coating. ACS Nano. 2012 Feb 28;6(2):1102-1108

[48] Quezada-Rentería JA, Cházaro-Ruiz LF, Rangel-Mendez JR. Synthesis of reduced graphene oxide (rGO) films onto carbon steel by cathodic electrophoretic deposition: Anticorrosive coating. Carbon. 2017 Oct;122:266-275

[49] Promphet N, Rattanawaleedirojn P, Rodthongkum N. Electroless NiP-TiO 2 sol-RGO: A smart coating for enhanced corrosion resistance and conductivity of steel. Surface and Coating Technology. 2017 Sep;325:604-610

[50] Nautiyal A, Qiao M, Cook JE, Zhang X, Huang T-S. High performance polypyrrole coating for corrosion protection and biocidal applications. Applied Surface Science. 2018 Jan;427:922-930 
[51] Bandeira RM, van Drunen J, Tremiliosi-Filho G, dos Santos JR, de Matos JME. Polyaniline/polyvinyl chloride blended coatings for the corrosion protection of carbon steel. Progress in Organic Coating. 2017 May;106:50-59

[52] Saravanan P, Jayamoorthy K, Ananda Kumar S. Design and characterization of nontoxic nano-hybrid coatings for corrosion and fouling resistance. Journal of Science: Advanced Materials and Devices - Elsevier. 2016 Sep;1(3):367-378

[53] Finkenstadt VL, Bucur CB, Côté GL, Evans KO. Bacterial exopolysaccharides for corrosion resistance on low carbon steel. Journal of Applied Polymer Science. 2017 Aug 5; 134(29):45032

[54] El-Meligi AA. Nanostructure of materials and corrosion resistance. In: Aliofkhazraei M, editor. Developments in Corrosion Protection. Rijeka: InTech; 2014

[55] Lakshmi RV, Aruna ST. Corrosion protection behaviour of silica-titania hybrid coatings embedded with silica nanoparticles. Surface Engineering. 2017 Jun 3;33(6):467-473

[56] Majumdar S, Paul B, Chakraborty P, Kishor J, Kain V, Dey GK. Formation of $\mathrm{Al}_{2} \mathrm{O}_{3} / \mathrm{FeAl}$ coatings on a $9 \mathrm{Cr}-1 \mathrm{Mo}$ steel, and corrosion evaluation in flowing $\mathrm{Pb}-17 \mathrm{Li}$ loop. Journal of Nuclear Materials. 2017 Apr;486:60-65

[57] Mohamed AMA, Abdullah AM, Younan NA. Corrosion behavior of superhydrophobic surfaces: A review. Arabian Journal of Chemistry. 2015 Nov;8(6):749-765

[58] Liu L, Xu F, Ma L. Facile fabrication of a superhydrophobic cu surface via a selective etching of high-energy facets. Journal of Physical Chemistry C. 2012 Sep 6;116(35): 18722-18727

[59] Liu L, Xu F, Yu Z, Dong P. Facile fabrication of non-sticking superhydrophobic boehmite film on al foil. Applied Surface Science. 2012 Sep;258(22):8928-8933

[60] Zhou X, Kong J, Sun J, Li H, He C. Stable superhydrophobic porous coatings from hybrid ABC Triblock copolymers and their anticorrosive performance. ACS Applied Materials \& Interfaces. 2017 Sep 6;9(35):30056-30063

[61] Alpysbaeva DA, Vershok DB, Emel'yanenko AM, Batishchev OV, Kuznetsov YI, Boinovich LB. Superhydrophobization of low-carbon steel with conversion coatings. Protection of Metals and Physical Chemistry of Surfaces. 2014 Dec;50(7):898-902

[62] Roselli SN, Lendvay-Györik G, Mészáros G, Deyá C, Romagnoli R. Anticorrosive water borne paints free from zinc and with reduced phosphate content. Progress in Organic Coating. 2017 Nov;112:27-36

[63] Zea C, Barranco-García R, Alcántara J, Chico B, Morcillo M, de la Fuente D. Hollow mesoporous silica nanoparticles loaded with phosphomolybdate as smart anticorrosive pigment. Journal of Coating Technology and Research. 2017 Jul;14(4):869-878

[64] Qiu P, Yang HF, Yang LJ, Chen ZS, Lv LJ, Song Y, et al. Enhanced inhibition of steel corrosion by L-cysteine under visible-light illumination. Materials and Corrosion. 2017 Sep;68(9):1004-1012 
[65] Dariva GC, Galio FA. Corrosion inhibitors - Principles, mechanisms and applications. In: Aliofkhazraei M, editor. Developments in Corrosion Protection [Internet]. Rijeka: InTech; 2014

[66] Bassey I. Recent advances in computational design of organic materials for corrosion protection of steel in aqueous media. In: Aliofkhazraei M, editor. Developments in Corrosion Protection. Rijeka: InTech; 2014

[67] Martinez R, Olivares-Xomelt O, Likhanov VN. Environmentally friendly corrosion inhibitors. In: Aliofkhazraei M, editor. Developments in Corrosion Protection. Rijeka: InTech; 2014

[68] Zhu Y, Free ML, Woollam R, Durnie W. A review of surfactants as corrosion inhibitors and associated modeling. Progress in Materials Science. 2017 Oct;90:159-223

[69] Caldas CM, Calheiros LF, Soares GB. Silica-polyaniline hybrid materials prepared by inverse emulsion polymerization for epoxy-based anticorrosive coating. Journal of Applied Polymer Science. 2017 Dec 15;134(47):45505

[70] Maia F, Silva AP, Fernandes S, Cunha A, Almeida A, Tedim J, et al. Incorporation of biocides in nanocapsules for protective coatings used in maritime applications. Chemical Engineering Journal. 2015 Jun;270:150-157

[71] Mousaa IM, Radi H. Photosynthesis of anticorrosive protective coatings for steel substrate based on acrylated oil containing unsaturated amino acid compounds. Progress in Organic Coating. 2017 Jun;107:18-28

[72] Keyvani A, Yeganeh M, Rezaeyan H. Application of mesoporous silica nanocontainers as an intelligent host of molybdate corrosion inhibitor embedded in the epoxy coated steel. Progress in Natural Science: Materials International. 2017 Apr;27(2):261-267

[73] Oguzie EE, Li Y, Wang SG, Wang F. Understanding corrosion inhibition mechanismsExperimental and theoretical approach. RSC Advances. 2011;1(5):866

[74] Guo L, Dong W, Zhang S. Theoretical challenges in understanding the inhibition mechanism of copper corrosion in acid media in the presence of three triazole derivatives. RSC Advances. 2014;4(79):41956-41967

[75] Guo L, Qi C, Zheng X, Zhang R, Shen X, Kaya S. Toward understanding the adsorption mechanism of large size organic corrosion inhibitors on an Fe(110) surface using the DFTB method. RSC Advances. 2017;7(46):29042-29050

[76] Malik MA, Hashim MA, Nabi F, Al-Thabaiti SA, Khan Z. Anti-corrosion ability of surfactants: A review. International Journal of Electrochemical Science. 2011;6(6):1927-1948

[77] Sığırcık G, Yildirim D, Tüken T. Synthesis and inhibitory effect of N,N'-bis(1-phenylethanol)ethylenediamine against steel corrosion in $\mathrm{HCl}$ media. Corrosion Science. 2017 May;120:184-193

[78] Meng Y, Ning W, Xu B, Yang W, Zhang K, Chen Y, et al. Inhibition of mild steel corrosion in hydrochloric acid using two novel pyridine Schiff base derivatives: A comparative study of experimental and theoretical results. RSC Advances. 2017;7(68):43014-43029 
[79] Krim O, Elidrissi A, Hammouti B, Ouslim A, Benkaddour M. Synthesis, characterization, and comparative study of pyridine derivatives as corrosion inhibitors of mild steel in $\mathrm{HCl}$ medium. Chemical Engineering Communications. 2009 Aug 31;196(12):1536-1546

[80] Heakal FE-T, Elkholy AE. Gemini surfactants as corrosion inhibitors for carbon steel. Journal of Molecular Liquids. 2017 Mar;230:395-407

[81] Agafonkina MO, Andreeva NP, Kuznetsov YI, Timashev SF. Substituted benzotriazoles as inhibitors of copper corrosion in borate buffer solutions. Russian Journal of Physical Chemistry A. 2017 Aug;91(8):1414-1421

[82] Khan G, Basirun WJ, Kazi SN, Ahmed P, Magaji L, Ahmed SM, et al. Electrochemical investigation on the corrosion inhibition of mild steel by Quinazoline Schiff base compounds in hydrochloric acid solution. Journal of Colloid and Interface Science. 2017 Sep; 502:134-145

[83] Qiang Y, Zhang S, Yan S, Zou X, Chen S. Three indazole derivatives as corrosion inhibitors of copper in a neutral chloride solution. Corrosion Science. 2017 Sep;126:295-304

[84] Li YZ, Xu N, Guo XP, Zhang GA. Inhibition effect of imidazoline inhibitor on the crevice corrosion of $\mathrm{N} 80$ carbon steel in the $\mathrm{CO}_{2}$-saturated $\mathrm{NaCl}$ solution containing acetic acid. Corrosion Science. 2017 Sep;126:127-141

[85] Zheludkevich ML, Yasakau KA, Poznyak SK, Ferreira MGS. Triazole and thiazole derivatives as corrosion inhibitors for AA2024 aluminium alloy. Corrosion Science. 2005 Dec; 47(12):3368-3383

[86] Guo L, Kaya S, Obot IB, Zheng X, Qiang Y. Toward understanding the anticorrosive mechanism of some thiourea derivatives for carbon steel corrosion: A combined DFT and molecular dynamics investigation. Journal of Colloid and Interface Science. 2017 Nov;506:478-485

[87] Fouda AS, Elmorsi MA, Fayed T, El Said IA. Oxazole derivatives as corrosion inhibitors for 316L stainless steel in sulfamic acid solutions. Desalination and Water Treatment. 2016;57(10):4371-4385

[88] Fouda AS, El-Aal AA, Kandil AB. The effect of some phthalimide derivatives on corrosion behavior of copper in nitric acid. Desalination. 2006 Nov;201(1-3):216-223

[89] Oguzie EE, Adindu CB, Enenebeaku CK, Ogukwe CE, Chidiebere MA, Oguzie KL. Natural products for materials protection: Mechanism of corrosion inhibition of mild steel by acid extracts of Piper Guineense. Journal of Physical Chemistry C. 2012 Jun 28; 116(25):13603-13615

[90] Dutta A, Saha SK, Adhikari U, Banerjee P, Sukul D. Effect of substitution on corrosion inhibition properties of 2-(substituted phenyl) benzimidazole derivatives on mild steel in $1 \mathrm{M} \mathrm{HCl}$ solution: A combined experimental and theoretical approach. Corrosion Science. 2017 Jul;123:256-266

[91] Ghazoui A, Benchat N, El-Hajjaji F, Taleb M, Rais Z, Saddik R, et al. The study of the effect of ethyl (6-methyl-3-oxopyridazin-2-yl) acetate on mild steel corrosion in $1 \mathrm{M} \mathrm{HCl}$. Journal of Alloys and Compounds. 2017 Feb;693:510-517 
[92] Rhattas K, Benmessaoud M, Doubi M, Hajjaji N, Srhiri A. Corrosion inhibition of copper in $3 \% \mathrm{NaCl}$ solution by derivative of Aminotriazole. Materials Sciences and Applications. 2011;02(04):220-225

[93] El-Sayed A-R, Shaker AM, Abd El-Lateef HM. Corrosion inhibition of tin, indium and tin-indium alloys by adenine or adenosine in hydrochloric acid solution. Corrosion Science. 2010 Jan;52(1):72-81

[94] Jiang S, Jiang L, Wang Z, Jin M, Bai S, Song S, et al. Deoxyribonucleic acid as an inhibitor for chloride-induced corrosion of reinforcing steel in simulated concrete pore solutions. Construction and Building Materials. 2017 Sep;150:238-247

[95] Jmiai A, El Ibrahimi B, Tara A, Oukhrib R, El Issami S, Jbara O, et al. Chitosan as an ecofriendly inhibitor for copper corrosion in acidic medium: Protocol and characterization. Cellulose. 2017 Sep;24(9):3843-3867

[96] Aiad I, El-Sukkary MM, Soliman EA, El-Awady MY, Shaban SM. Inhibition of mild steel corrosion in acidic medium by some cationic surfactants. Journal of Industrial and Engineering Chemistry. 2014 Sep;20(5):3524-3535

[97] Badr EA. Inhibition effect of synthesized cationic surfactant on the corrosion of carbon steel in 1M HCl. Journal of Industrial and Engineering Chemistry. 2014 Sep;20(5):3361-3366

[98] Palomar ME, Olivares-Xometl CO, Likhanova NV, Pérez-Navarrete J-B. Imidazolium, pyridinium and dimethyl-ethylbenzyl ammonium derived compounds as mixed corrosion inhibitors in acidic medium. Journal of Surfactants and Detergents. 2011 Apr;14 (2):211-220

[99] Sangeetha Y, Meenakshi S, SairamSundaram C. Corrosion mitigation of N-(2-hydroxy3-trimethyl ammonium)propyl chitosan chloride as inhibitor on mild steel. International Journal of Biological Macromolecules. 2015 Jan;72:1244-1249

[100] Shihab MS, Mahmood AF. Experimental and theoretical study of some N-pyridinium salt derivatives as corrosion inhibitors for mild-steel in $1 \mathrm{M} \mathrm{H}_{2} \mathrm{SO}_{4}$ : Port. Electrochimica Acta. 2017;35(6):39-51

[101] Abd El-Lateef HM, Abo-Riya MA, Tantawy AH. Empirical and quantum chemical studies on the corrosion inhibition performance of some novel synthesized cationic gemini surfactants on carbon steel pipelines in acid pickling processes. Corrosion Science. 2016 Jul;108:94-110

[102] Hegazy MA, Abd El-Rehim SS, Badr EA, Kamel WM, Youssif AH. Mono-, di- and tetracationic surfactants as carbon steel corrosion inhibitors. Journal of Surfactants and Detergents. 2015 Nov;18(6):1033-1042

[103] Kaczerewska O, Leiva-Garcia R, Akid R, Brycki B. Efficiency of cationic gemini surfactants with 3-azamethylpentamethylene spacer as corrosion inhibitors for stainless steel in hydrochloric acid. Journal of Molecular Liquids. 2017;247:6-13 
[104] Labena A, Hegazy MA, Horn H, Muller E. Cationic gemini surfactant as a corrosion inhibitor and a biocide for high salinity sulfidogenic bacteria originating from an oilfield water tank. Journal of Surfactants and Detergents. 2014;17:419-431

[105] Mobin M, Aslam R, Aslam J. Non toxic biodegradable cationic gemini surfactants as novel corrosion inhibitor for mild steel in hydrochloric acid medium and synergistic effect of sodium salicylate: Experimental and theoretical approach. Materials Chemistry and Physics. 2017 Apr;191:151-167

[106] Mobin M, Aslam R, Zehra S, Ahmad M. Bio-/environment-friendly cationic gemini surfactant as novel corrosion inhibitor for mild steel in $1 \mathrm{M} \mathrm{HCl}$ solution. Journal of Surfactants and Detergents. 2017 Jan;20(1):57-74

[107] Mobin M, Masroor S. Cationic gemini surfactants as novel corrosion inhibitor for mild steel in 1M HCl. International Journal of Electrochemical Science. 2012;7:6920-6940

[108] Sharma V, Borse M, Jauhari S, Pai KB, Devi S. New hydroxylated cationic gemini surfactants as effective corrosion inhibitors for mild steel in hydrochloric acid medium. Tenside, Surfactants, Detergents. 2005;42(3):163-167

[109] Tawfik SM. Ionic liquids based gemini cationic surfactants as corrosion inhibitors for carbon steel in hydrochloric acid solution. Journal of Molecular Liquids. 2016 Apr;216: 624-635

[110] Tawfik SM, Abd-Elaal AA, Aiad I. Three gemini cationic surfactants as biodegradable corrosion inhibitors for carbon steel in $\mathrm{HCl}$ solution. Research on Chemical Intermediates. 2016 Feb;42(2):1101-1123

[111] Asefi D, Arami M, Mahmoodi NM. Comparing chain length effect of single chain and gemini surfactants on corrosion inhibition of steel in acid. ECS Transactions. 2011;35(17): 89-101

[112] Zhang Q, Gao Z, Xu F, Zou X. Adsorption and corrosion inhibitive properties of gemini surfactants in the series of hexanediyl-1,6-bis-(diethyl alkyl ammonium bromide) on aluminium in hydrochloric acid solution. Colloids and Surfaces A: Physicochemical and Engineering Aspects. 2011 May;380(1-3):191-200

[113] Hegazy MA, Atlam FM. Three novel bolaamphiphiles as corrosion inhibitors for carbon steel in hydrochloric acid: Experimental and computational studies. Journal of Molecular Liquids. 2016 Jun;218:649-662

[114] Abdallah M, Eltass HM, Hegazy MA, Ahmed H. Adsorption and inhibition effect of novel cationic surfactant for pipelines carbon steel in acidic solution. Protection of Metals and Physical Chemistry of Surfaces. 2016 Jul;52(4):721-730

[115] Hegazy MA, Abdallah M, Awad MK, Rezk M. Three novel di-quaternary ammonium salts as corrosion inhibitors for API X65 steel pipeline in acidic solution. Part I: Experimental results. Corrosion Science. 2014 Apr;81:54-64 
[116] Kaczerewska O, Brycki B, Leiva-García R, Akid R. Cationic Gemini Surfactants as Corrosion Inhibitors of Stainless Steel (AISI 304) in 3M Hydrochloric Acid; Praga; 2017

[117] Qiu L-G, Wu Y, Wang Y-M, Jiang X. Synergistic effect between cationic gemini surfactant and chloride ion for the corrosion inhibition of steel in sulphuric acid. Corrosion Science. 2008 Feb;50(2):576-582

[118] Z-Y W, Fang Z, Qiu L-G, Wu Y, Li Z-Q, Xu T, et al. Synergistic inhibition between the gemini surfactant and bromide ion for steel corrosion in sulphuric acid. Journal of Applied Electrochemistry. 2009 Jun;39(6):779-784

[119] Zhao J, Duan H, Jiang R. Synergistic corrosion inhibition effect of quinoline quaternary ammonium salt and Gemini surfactant in $\mathrm{H}_{2} \mathrm{~S}$ and $\mathrm{CO}_{2}$ saturated brine solution. Corrosion Science. 2015 Feb;91:108-119

[120] Altamirano RH, Cervantes VYM, Rivera LSZ, Conde HIB, Ramirez SL. Gemini surfactants, process of manufacture and use as multifunctional corrosion inhibitors. US 9023 785 B2; 2015

[121] Henry KM, Hicks KD. Bis-quaternary ammonium salt corrosion inhibitors. US 8999315 B2; 2015

[122] El-Mahdy GA, Atta AM, Al-Lohedan HA, Ezzat AO. Influence of green corrosion inhibitor based on chitosan ionic liquid on the steel corrodibility in chloride solution. International Journal of Electrochemical Science. 2015;10:5812-5826

[123] Muyzer G, Stams AJM. The ecology and biotechnology of sulphate-reducing bacteria. Nature Reviews. Microbiology [Internet]. 2008 May;7; [cited 2017 Sep 19] Available from: http://www.nature.com/doifinder/10.1038/nrmicro1892

[124] Maluckov BS. Corrosion of steels induced by microorganisms. Metallurgical and Materials Engineering. 2012;18(3):223-232

[125] Kip N, van Veen JA. The dual role of microbes in corrosion. The ISME Journal. 2015 Mar;9(3):542-551

[126] Videla HA. Prevention and control of biocorrosion. International Biodeterioration and Biodegradation. 2002;49(4):259-270

[127] Miranda E, Bethencourt M, Botana FJ, Cano MJ, Sánchez-Amaya JM, Corzo A, et al. Biocorrosion of carbon steel alloys by an hydrogenotrophic sulfate-reducing bacterium Desulfovibrio capillatus isolated from a Mexican oil field separator. Corrosion Science. 2006 Sep;48(9):2417-2431

[128] Wagner M, Ivleva NP, Haisch C, Niessner R, Horn H. Combined use of confocal laser scanning microscopy (CLSM) and Raman microscopy (RM): Investigations on EPS Matrix. Water Research. 2009 Jan;43(1):63-76

[129] Pradier CM, Rubio C, Poleunis C, Bertrand P, Marcus P, Compère C. Surface characterization of three marine bacterial strains by Fourier transform IR, X-ray photoelectron 
spectroscopy, and time-of-flight secondary-ion mass spectrometry, correlation with adhesion on stainless steel surfaces. The Journal of Physical Chemistry. B. 2005 May;109(19): 9540-9549

[130] Lee M, Kim H, Seo J, Kang M, Kang S, Jang J, et al. Surface zwitterionization: Effective method for preventing oral bacterial biofilm formation on hydroxyapatite surfaces. Applied Surface Science. 2018 Jan;427:517-524

[131] Enning D, Garrelfs J. Corrosion of iron by sulfate-reducing bacteria: New views of an old problem. Applied and Environmental Microbiology. 2014 Feb 15;80(4):1226-1236

[132] Michalska J, Sowa M, Socha RP, Simka W, Cwalina B. The influence of Desulfovibrio desulfuricans bacteria on a Ni-Ti alloy: Electrochemical behavior and surface analysis. Electrochimica Acta. 2017 Sep;249:135-144

[133] Seo H, Roh Y. Biotransformation and its application: Biogenic Nano-catalyst and metalreducing-bacteria for remediation of $\mathrm{Cr}(\mathrm{VI})$-contaminated water. Journal of Nanoscience and Nanotechnology. 2015 Aug 1;15(8):5649-5652

[134] Labena A, Hegazy MA, Horn H, Müller E. The biocidal effect of a novel synthesized gemini surfactant on environmental sulfidogenic bacteria: Planktonic cells and biofilms. Materials Science and Engineering: C. 2015 Feb;47:367-375

[135] Labena A, Hegazy MA, Horn H, Müller E. Cationic gemini surfactant as a corrosion inhibitor and a biocide for high salinity sulfidogenic bacteria originating from an oilfield water tank. Journal of Surfactants and Detergents. 2014 May;17(3):419-431

[136] Mishra B, Lushnikova T, Golla RM, Wang X, Wang G. Design and surface immobilization of short anti-biofilm peptides. Acta Biomaterialia. 2017 Feb;49:316-328

[137] Mishra B, Lushnikova T, Wang G. Small lipopeptides possess anti-biofilm capability comparable to daptomycin and vancomycin. RSC Advances. 2015;5(73):59758-59769

[138] Danaee I, Ghasemi O, Rashed GR, Rashvand Avei M, Maddahy MH. Effect of hydroxyl group position on adsorption behavior and corrosion inhibition of hydroxybenzaldehyde Schiff bases: Electrochemical and quantum calculations. Journal of Molecular Structure. 2013 Mar;1035:247-259

[139] Migahed MA, Shaban MM, Fadda AA, Ali TA, Negm NA. Synthesis of some quaternary ammonium gemini surfactants and evaluation of their performance as corrosion inhibitors for carbon steel in oil well formation water containing sulfide ions. RSC Advances. 2015;5(126):104480-104492

[140] Obot IB, Macdonald DD, Gasem ZM. Density functional theory (DFT) as a powerful tool for designing new organic corrosion inhibitors. Part 1: An overview. Corrosion Science. 2015 Oct;99:1-30

[141] Zarrok H, Oudda H, Zarrouk A, Salghi R, Hammouti B, Bouachrine M. Weight loss measurement and theoretical study of new pyridazine compound as corrosion inhibitor for C38 steel in hydrochloric acid solution. Pharma Chemica. 2011;3(6):576-590 
